\title{
Animal models of PTSD: a challenge to be met
}

\author{
Gal Richter-Levin ${ }^{1,2,3} \cdot$ Oliver Stork $^{4,5} \cdot$ Mathias V. Schmidt $^{6}$
}

Received: 23 September 2017 / Revised: 13 August 2018 / Accepted: 11 September 2018 / Published online: 19 October 2018

(c) The Author(s) 2018. This article is published with open access

\begin{abstract}
Recent years have seen increased interest in psychopathologies related to trauma exposure. Specifically, there has been a growing awareness to posttraumatic stress disorder (PTSD) in part due to terrorism, climate change-associated natural disasters, the global refugee crisis, and increased violence in overpopulated urban areas. However, notwithstanding the increased awareness to the disorder, the increasing number of patients, and the devastating impact on the lives of patients and their families, the efficacy of available treatments remains limited and highly unsatisfactory. A major scientific effort is therefore devoted to unravel the neural mechanisms underlying PTSD with the aim of paving the way to developing novel or improved treatment approaches and drugs to treat PTSD. One of the major scientific tools used to gain insight into understanding physiological and neuronal mechanisms underlying diseases and for treatment development is the use of animal models of human diseases. While much progress has been made using these models in understanding mechanisms of conditioned fear and fear memory, the gained knowledge has not yet led to better treatment options for PTSD patients. This poor translational outcome has already led some scientists and pharmaceutical companies, who do not in general hold opinions against animal models, to propose that those models should be abandoned. Here, we critically examine aspects of animal models of PTSD that may have contributed to the relative lack of translatability, including the focus on the exposure to trauma, overlooking individual and sex differences, and the contribution of risk factors. Based on findings from recent years, we propose research-based modifications that we believe are required in order to overcome some of the shortcomings of previous practice. These modifications include the usage of animal models of PTSD which incorporate risk factors and of the behavioral profiling analysis of individuals in a sample. These modifications are aimed to address factors such as individual predisposition and resilience, thus taking into consideration the fact that only a fraction of individuals exposed to trauma develop PTSD. We suggest that with an appropriate shift of practice, animal models are not only a valuable tool to enhance our understanding of fear and memory processes, but could serve as effective platforms for understanding PTSD, for PTSD drug development and drug testing.
\end{abstract}

\section{Introduction}

Gal Richter-Levin

galrichterlevin@gmail.com

1 Sagol Department of Neurobiology, University of Haifa, Haifa, Israel

2 The Integrated Brain and Behavior Research Center (IBBR), University of Haifa, Haifa, Israel

3 Psychology Department, University of Haifa, Haifa, Israel

4 Department of Genetics \& Molecular Neurobiology, Institute of Biology, Otto-von-Guericke-University Magdeburg, Leipziger Str. 44, 39120 Magdeburg, Germany

5 Center for Behavioral Brain Sciences, Universitätsplatz 2, 39106 Magdeburg, Germany

6 Department of Stress Neurobiology and Neurogenetics, Max Planck Institute of Psychiatry, Munich, Germany

\section{Posttraumatic stress disorder (PTSD)}

Since the early days of mankind, traumatic events have been known to lead to disabling responses [1], but only in 1980 was PTSD officially included as a diagnostic category in the Diagnostic and Statistical Manual of Mental Disorders-third edition (DSM-III). However, in recent years the increasing societal challenges have brought PTSD to the center of attention. Combat-related trauma and associated PTSD are of considerable relevance to military, but military personnel are certainly not the main population associated with the disorder. Climate changes have led to large-scale natural disasters, affecting civilian populations. The global refugee crisis has exposed millions of children, women, and men to danger and exploitation. Further, people living in relatively 
stable communities are increasingly exposed to work and car accidents, terror attacks, sexual and physical attacks, or domestic violence that may lead to PTSD. The 12-month prevalence of PTSD across the world is estimated to be of 3-4\% [2], and its estimated prevalence in conflict-affected populations increases to over $15 \%$ [3]. Furthermore, PTSD is associated with comorbidity with depression or substance abuse [4], which exacerbates the outcome and complicates treatment. In fact, many authors consider PTSD a rather heterogeneous disorder which likely contains several subtypes, such as complex PTSD, with specific characteristics such as somatization, dissociation, and affect dysregulation [5] if not distinct sub-pathologies [6, 7].

While PTSD is now recognized as a major health challenge, there is as yet only partially effective treatment for the disorder. First-line treatments of PTSD are forms of cognitive therapy, mainly cognitive-behavioral therapy, cognitive therapy, and exposure therapy [8, 9]. While effective in many cases, nonresponse to psychological therapies for PTSD may be as high as 50\% [10]. The situation with psychopharmacology treatment is probably even worse. Despite the fact that drugs, such as serotonin selective reuptake inhibitors (SSRIs), are often prescribed to PTSD patients, several meta-analysis studies suggest that in fact the efficacy of such treatments is equivalent to that of placebo treatment, and even in studies that ascribe some beneficial effects to such treatments, its efficacy is minor $[11,12]$. Low efficacy of SSRIs is not specific to PTSD, as similar concern has also been raised regarding their efficacy in major depression [13]. The World Health Organizationsupported meta-analysis study by Hoskins et al. [14] indicates that the effect sizes for pharmacological treatments for PTSD compared with placebo are low and inferior to those reported for psychological treatments [14].

The low efficacy of psychopharmacological treatment of PTSD could have been expected to be translated to attempts to introduce novel drugs and drugs of novel mechanisms of action. However, the drugs in use are in principle not different from those used more than 40 years ago [15], and there seems to be an agreement that meaningful advancements with regard to the pharmacotherapy of PTSD will likely come only from the identification of mechanistically novel agents [13]. Despite the obvious need for better PTSD drugs, leading pharmaceutical companies have abandoned psychiatry drug-discovery programs, since those are considered high-risk activity. A critical factor contributing to this outcome is the poor (or too one-sided) understanding of the neural mechanisms underlying PTSD and the uncertainty of whether animal models of trauma exposure and fear memory are sufficient to predict a positive treatment outcome with a sufficient level of certainty [16, 17].

On the other hand, there is intensive academic research aiming at elucidating the neural mechanisms underlying
PTSD, both in patients and in animal models. A recent review indicates four brain functions which are considered to play a role in the psychopathology of PTSD, including emotion regulation and executive function, threat detection, contextual processing, and fear learning. The review brings evidence for the involvement of associated brain circuits which are suggested to be dysfunctional in PTSD patients [18]. These are brain regions that have long been indicated in PTSD, including the amygdala, the medial prefrontal cortex, the anterior cingulate cortex, and the hippocampus [18]. While these findings are of great importance to our understanding of the neural circuits related to PTSD, a more thorough cellular and molecular understanding of the mechanisms of PTSD is required in order to be translated to novel or improved pharmacological agents.

\section{Clinical characteristics of PTSD}

In 2013, the American Psychiatric Association revised the PTSD diagnostic criteria in the fifth edition of its Diagnostic and Statistical Manual of Mental Disorders (DSM-5) [19]. The revised diagnostic criteria include:

A. Direct or indirect exposure to a traumatic event, with an emphasis on the extraordinary magnitude of the event. This emphasis and the implications to animal models of PTSD will be further discussed below.

B. Intrusive symptoms.

C. Avoidance behavior.

D. Negative alterations in cognitions and mood.

E. Alterations in arousal and reactivity.

F. Duration of symptoms of more than 1 month.

G. Functional significance.

H. As always in psychiatric diagnosis-symptoms are not due to medication, substance use, or other illness.

In addition, the DSM-5 introduced an additional subtype of PTSD for children ages 6 years and younger, with a cluster of symptoms adapted to those young ages.

When considering modeling PTSD in animals, there are clearly some symptoms, like intrusive thoughts, which are not possible or are difficult to measure. Nevertheless, in each set of criteria there are measures that can be carried out within the context of the animal model. For example, intense or prolonged distress after exposure to traumatic reminders or marked physiologic reactivity after exposure to trauma-related stimuli may be measured in rodents as part of assessing criterion B 'Intrusive symptoms'. Likewise, avoidance behavior in face of trauma-related external reminders may be measured for criterion C 'Avoidance behavior'. Criterion D, of negative alterations in cognitions and mood, may be assessed by several, well-established tests such as tests of hedonic preference, social preference, and motivation. Measuring symptoms associated with criterion E, relating 
to alterations in arousal and reactivity, are of course quite straightforward to measure in animals, since there are many validated tests for irritability or aggression, hypervigilance, startle reaction, and sleep parameters.

It is also important to pay attention to the fact that according to criterion $\mathrm{F}$, relevant symptoms are those that last for more than 1 month. It is not clear if 1 month in human's life is translated exactly to 1 month in rodent's life, but clearly it is of importance to consider symptoms which last for a significant period of time after the exposure to the trauma.

Importantly, criterion $G$ refers to the functional significance of the symptoms. This is an aspect which in animal models has not been given enough attention as yet. Probably the most important implication of the symptoms above for patients is the resultant impairment of social and occupational functioning. Identifying a clear functional impairment associated with those symptoms of PTSD which can be measured in animals will be significant in securing the validity of the definition of an animal as clearly being affected.

In parallel to the criteria listed in DSM-5, more symptom-based stratifications of psychiatric disorders have been proposed, most prominently the Research Domain Criteria (RDoC) concept framed by the US National Institute of Mental Health (NIMH) [20]. In contrast to the disease classification and disease-specific diagnostic criteria of the DSM-5, RDoC defines 5 domains or constructs of observable behavior and neurobiological measures that have common underlying neurobiological circuits. These domains defined so far include (1) negative valence, (2) positive valence, (3) cognitive processes, (4) social processes, and (5) arousal [21]. Each of these domains can consequently be analyzed on different levels, ranging from genes and molecules over cells and neural circuits up to physiology and behaviors. As both the research domains and the levels of analysis are highly translational between humans and animal models, the RDoC concept also holds immense promise with regard to PTSD research. Of the defined five general domains, at least four are altered in PTSD patients (negative valence, positive valence, cognitive processes, and arousal), and these can be modeled in animals. Implementing the $\mathrm{RDoC}$ concept in clinical practice as well as translational research will take time, though, and many aspects of this concept are still heavily debated. For example, additional domains that are affected in PTSD patients (among others) have been proposed, such as stress and emotional regulation [22]. Nonetheless, when considering to model PTSD in animals it is highly useful to take the RDoC concept into account and align the model with the research domains and levels of analysis described herein.

\section{Genetics of PTSD: mechanistic insights from patient studies}

Twin studies have demonstrated a heritability of PTSD risk of up to $30-40 \%$, indicating the contribution to genetic risk factors to the disorder [23]. When considering that many genetic risk factors for PTSD are likely modulated by environmental influences via gene $\times$ environment interactions, the actual genetic contribution to PTSD may be even higher. Unfortunately, similar to the situation for many other psychiatric disorders, such as major depression [24] (often comorbid to PTSD), the use of unbiased genomewide association studies to identify novel candidate genes has so far only been of limited success [25, 26]. Ongoing efforts with larger sample size may yet reveal reproducible hits, but the effect size of single polymorphisms is likely to be very small. Moderately better success has been obtained by investigating candidate genes, especially when the studies were focusing on gene $\times$ environment interactions.

The involvement of the stress system, especially the hypothalamic-pituitary-adrenal (HPA) axis is well documented for PTSD [27]. Multiple studies reported a hypoactive HPA axis in PTSD patients, related especially to a hypersensitive glucocorticoid receptor (GR) which is directly responsible for negative feedback regulation of the HPA axis [28]. Consequently, polymorphisms in genes involved in negative feedback regulation of HPA axis activity have been identified to be significantly associated with PTSD [29]. Next to described risk polymorphisms in the glucocorticoid receptor gene itself, the GR co-chaperone FKBP51 (encoded by the FKBP5 gene) emerged as a very interesting PTSD candidate gene. The best understood function of FKBP51 is the reduction of GR sensitivity. Importantly, FKBP5 is one of the most GR-regulated genes in the body, thereby forming an ultra-short feedback loop via mediation of GR sensitivity [30]. Polymorphisms in the regulatory region of the FKBP5 gene affect the GRdependent transcriptional regulation of FKBP51 and consequently the sensitivity of the GR [31, 32]. The same polymorphism has been associated to interact with early-life trauma to predict adult PTSD [33-36], providing strong clinical evidence for a role of FKBP51 in moderating the risk for PTSD dependent on early-life experiences. While specific drugs acting on FKBP51 have now been developed $[37,38]$, a proof of principle that those drugs act in animal models of PTSD is still missing.

As learning processes and fear memory are central in PTSD pathology, it is not surprising that neural plasticity genes have also been implemented in this disorder, especially brain-derived neurotrophic factor (BDNF). BDNF is crucial for neural plasticity, as it promotes cellular growth and synaptic changes, and is also regulated via the GR. A polymorphism in the human BDNF gene, the so-called 
Val66Met polymorphism, gives rise to a functional BDNF variant. Carriers of the Met allele are considerably more frequent among PTSD patients compared to controls and homozygous Met carriers are at higher risk to suffer from PTSD [39]. However, BDNF has been linked to a variety of other psychiatric disorders, especially mood disorders [40], and hence it is yet unclear how specific the BDNF effects are in relation to PTSD symptomatology.

A third example for candidate-driven studies for PTSD is genes involved in monoaminergic signaling in the brain. Several studies have reported increased PTSD risks related to serotonergic or dopaminergic transporters [41, 42]. On the other hand, several studies and meta-analyses failed to replicate these associations [43], again indicating that the effect sizes of single polymorphisms are generally low and likely need to be studied using more complex gene $x$ environment interactions. Overall, it is clear that the lack of a better understanding of the cellular and molecular mechanisms associated with PTSD hampers a better understanding and ultimately a more effective treatment of the disorder.

\section{Translational insights from established PTSD animal models}

The main tool allowing detailed investigation into cellular and molecular mechanisms associated with a disease is the employment of animal models, which enable the resolution required for such studies. Animal models for understanding the neurobiology of PTSD are expected to unravel the cellular and molecular mechanisms associated with PTSD, which should serve to reveal novel targets for drug development. Furthermore, such models are also required as a platform for novel drug testing.

The fact that, in contrast to other psychiatric disorders, PTSD onset is associated with a clear triggering event- the exposure to a trauma-gave rise to hopes that this disorder will be relatively straightforward to model, and thus lead to relatively rapid progress in the understanding of PTSD neurobiology and the development of effective novel drugs $[44,45]$.

A good example for the successful use of established PTSD animal models in elucidating the involvement of a clinical candidate gene in PTSD pathology is BDNF [46]. Differences in BDNF expression levels have been reported for a number of PTSD animal models, although there is no clear picture regarding the direction of change [47-49]. Interestingly, mice carrying the human Met allele were shown to display delayed extinction learning which is in line with the human genetic associations and suggests a causal link to PTSD pathology [50]. Furthermore, BDNF infused into the infralimbic medial prefrontal cortex reduces conditioned fear for up to
$48 \mathrm{~h}$, suggesting that boosting BDNF activity in certain brain circuits may be used to treat PTSD symptoms [47]. With the development of small-molecule mimetics for the tropomyosin receptor kinase B (TrkB) receptor [51], potential new treatment options for PTSD arise. However, the differential and widespread role of BDNF in various brain regions makes this a difficult target for pharmacological intervention.

The situation is similar for molecular insights in HPA axis functioning and interventions from animal models of PTSD. Several studies confirmed GR-dependent signaling abnormalities in PTSD animal models. For example, Daskalakis et al. [52] identified GR signaling as the convergent pathway associated with individual differences in a rat model of PTSD in both males and females. Further, the GR co-chaperone FKBP51 is dynamically regulated in fear extinction models and linked to GR agonist-dependent enhanced fear extinction [53], thereby supporting the human FKBP51-related genetic findings. The first selective FKBP51 antagonist has recently been developed [37] and shown to reduce anxiety in mice [38], underlining the need for further studies with these compounds in PTSD models.

There are more examples of increased mechanistic insights gained from established PTSD animal models [54] (see Table 1). Furthermore, animal models have started to examine the possibility of device-based treatments for PTSD, such as deep-brain stimulation (DBS). However, despite intensive research (e.g., reviewed in refs. [55-58]), the expectation that the in-depth understanding of the mechanistic underpinnings of the available PTSD animal models, and the hope for identifying novel and more effective drugs based on these insights, remain unfulfilled as yet [15].

\section{The need for more effective animal models of PTSD}

Developing an effective and translational animal model of PTSD is not a trivial task. As with other psychiatric disorders [59,60], there are inherent challenges from both ends of the mission. PTSD is not a well-defined disorder. The definition and diagnosis of PTSD in humans is based on behavioral symptoms and self-reports, without any objective parameters, and there is a large overlap with other disorders, including mood disorders, anxiety disorders, as well as alcohol and drug abuse [61-63]. As a result, it is not clear what is required in an animal model in order for the model to reliably reflect the human disorder.

It is also not trivial to use the conventional ways to validate an animal model of PTSD. The main validation approaches are simply not possible [64]. Probably the strongest type of model validation is based on 'construct validation'. Construct validity points to the degree of similarity between the mechanisms underlying behavior in the 
Table 1 Factors with genetic PTSD/PTSD feature association in human and corresponding findings in animal models

Gene (human findings)

Finding in animal model(s)

HPA stress axis

Glucocorticoid receptor [211, 212]

FKBP5 [215, 216]

... Shows interaction with juvenile adversity on PTSD development $[33,36]$

CRH/CRHR [221-223]

... Mediates the effect of juvenile adversity on cortisol response [227]

PACAP / PAC1R [230]

\section{Serotonergic system}

5-HT transporter [233-236]

... Mediates interaction of childhood adversity and sex on hippocampal volume [239]

5-HT1A receptor [242]

\section{Dopaminergic system}

Dopamine receptor 2 [246]

Catechyl- $O$-methyltransferase [249]

... Mediates lastingly increased cortisol levels in adolescents after stress [250]

\section{Glutamatergic system}

mGluR5 [252]

\section{GABAergic system}

Glutamic acid decarboxylase [249, 253]

GABAA receptor
GR stimulation improves fear extinction after stress-enhanced fear conditioning [53]

GR expression is increased in the PFC after single prolonged stress [213]

Transcriptional changes of the GR pathway in amygdala and hippocampus after predator scent [52]

GR mediates potentiation of fear memory after single prolonged stress [214]

FKBP5 knockout prevents age-induced impairment of stress resilience [217] FKBP5 knockdown in the rat infralimbic cortex enhances extinction [218]

Reduced FKBP5 in expression in the rat PFC after early-life stress [219] Lastingly increased FKBP5 expression in rat BLA after chronic mild stress in adolescences [220]

Conditional ablation of CRHR1 from forebrain neurons impairs consolidation of remote fear memory [224]

CRHR2 mediates stress-enhanced fear conditioning via Mek1/2 activation [97]

CRHR2 knockdown in BNST provides resilience in a stress-enhanced fear learning paradigm [225]

CRHR2 overexpression in BNST attenuates predator stress-induced fear in susceptible animals [226]

Transient prepubertal overexpesion of $\mathrm{CRH}$ in the forebrain increases vulnerability [228]

Early-life stress $\times 5$-HTT interaction controls $C R H$ Promoter methylation in adult [229]

PAC1R-/- show reduced anxiety [231]

PACAP HET produce increased vulnerability to combined juvenile and adult chronic mild stress [232]

5-HTT-/- mice show fear extinction deficits [237]

5-HTT inhibitor venlafaxine relieves forced swim stress after single prolonged stress [238]

5-HTT mutation interacts with maternal separation stress to control HPA maturation and behavior in adult rats [240, 241]

5-HT1A knockout shows increased context fear memory [243]

5-HT1A mediates fear extinction deficits after early-life stress [100] Increased 5-HT1A expression in dorsal raphe after single prolonged stress [244]

5-HT1A mediates recovery of inhibitory control in the dentate gyrus after juvenile stress [245]

Regulation of DRD2 expression in N. accumbens by prenatal stress [247] Reduced DRD2 expression in amygdala after social stress induction of increased fear [248]

COMT-/- mice are vulnerable to cannabinoid treatment in adolescence, altering PPI in adult [251]

Mediates stress-enhanced fear memory through interaction with Homer [98]

GAD2 knockout shows increased, generalized fear [254]

GAD2 knockout displays extinction deficits [255]

GAD2 haplodeficient mice show resilience to fear generalization after juvenile stress [256]

Rescue of PTSD symptoms in single prolonged stress model by midazolam [257] 
Table 1 (continued)

Gene (human findings)

... Interacts with childhood trauma towards risk for PTSD [258]

\section{GABA-B}

receptor

... Only pharmacological evidence

Cannabinoid receptor 1

... Interacts with childhood abuse to increase fear in PTSD [268]

\section{Neuropeptides}

Neuropeptide Y [270]

Nociceptin/Orphanin FQ [272]

Tachikinin 2

Brain-derived neurotrophic factor [246, 275-278]

... Child abuse moderatesVal66Met induced increase of threat reactivity in PTSD veterans [284]

Oxytocin/OT Receptor [286]

... Mediates effect of early-life stress on adult depression anxiety stress scale [289]

\section{Others}

Apolipoprotein E2 [290, 291]

Interleukin-1 receptor [92]

S100B, only serum levels

Regulator of $\mathrm{G}$ protein signaling 2 [91]

Voltage gated calcium channel subunit alpha 1C [293]

ROR alpha [295]

... Mediates effect of early-life stress on posttraumatic stress response [297]
Finding in animal model(s)

Altered GABAA receptor alpha subunit expression in juvenile stressed rats [259]

Reduced allopregnanolone after social isolation and rescue of social isolation induced fear behavior by ganaxolone [260, 261]

Knockout of GABAB1a results in fear memory generalization [262]

GABA-B antagonist induces fear generalization in mice [263]

GABA-B antagonist blocks fear extinction in rats [264]

Knockout mice show an increased response to repeated stress exposures [265]

CB1 antagonist blocks conditioned fear extinction [266]

Increased expression in dorsal striatum after a single prolonged stress [267]

Disruption in adolescence alters adult anxiety-related behavior [269]

NPY mediates resilience to effects of predator odor exposure [155] Reduced expression is observed following chronic variable stress shock [271]

Inhibition in the dentate gyrus impairs context salience determination in fear conditioning [110]

N/OFQ acts as anxiolytic following single prolonged stress in rats [273]

Overexpression in central amygdala mediates consolidation of stressenhanced fear in mice [274]

Impaired fear extinction found in BDNF-e4 mutant mice [279]

BDNF promoter methylation is increased in the hippocampus after psychosocial stress [280]

Increased BDNF signaling is observed after single prolonged stress [49]

BDNF cko show enhanced fear learning [281]

BDNF knockdown in the hippocampus impairs fear extinction [282]

Impaired fear extinction in BDNF Met-Val mutant mice [283]

Critical for context fear memory in adolescent mice [285]

Reduced anxiety of OT-/- males mice [287]

Increased anxiety in OT $-/-$ females [288]

OT-/- mice show reduced vocalization during maternal separation [287]

APOE2-/- mice display lack of fear extinction [291, 292]

APOE2-/- mice show increased response to chronic variable stress [292]

IL-1-/- mice display increase in conditioned fear [89]

Blockage of IL-1 in the hippocampus ameliorates stress-enhanced fear memory [95]

Knockout mice show increased conditioned fear [93]

Increased CSF levels found after maternal stress+adult shock [94]

RGS2-/- mice show increased context fear memory [90]

Enhanced fear memory in CACNA1C $+/$ - mutant mice [294]

ROR-A-I- mice show increased corticosterone response to novelty stress [296]

ROR-A promoter methylation upon maternal separation stress prevents differentiation of adult neural precursors [298]

The italic fields indicate findings related to juvenile adversity

model and those underlying the behavior in the condition which is being modeled [65]. While there are strongly based hypotheses regarding the neural mechanisms which underlie PTSD [18], the actual neural basis of PTSD is as yet not known, and thus it is not possible to validate the model relying on construct validity.

Likewise, may be the most common approach to validate an animal model of a disease is by pharmacological 
validation. It requires that a pharmacological treatment which reduces symptoms in humans will reduce the symptoms in the animal model with similar efficacy. However, there is no 'gold standard' pharmacological treatment in PTSD, and available treatments have low efficacy $[11,12]$.

\section{Towards an effective animal model of PTSD}

The validity of existing PTSD animal models and their limitations have been reviewed before [58, 66-68], but a clear path for an improvement of the current situation is still under debate. The stalled progress in providing better understanding and improved treatments [15, 69] has been a major factor contributing to the withdrawal of leading pharmaceutical companies from psychiatry drug development [16, 17], but in addition, it raised serious doubts regarding the possibility of animal models to contribute to PTSD-related research and to related drug development (see, e.g., refs. [15, 69]).

Based on findings from recent years, we would like to propose a different view which does not ignore the progress so far but suggests that, with an appropriate shift of practice, animal models can become an even more valuable tool to enhance our understanding of the disorder, and could serve as effective platforms for drug development and drug testing. Towards that end, we here critically review various aspects of animal models of PTSD and propose researchbased modifications that we believe are required in order to overcome some of the shortcomings of previous practice.

\section{When should the effects be measured?}

Initially, the majority of individuals exposed to a severe trauma exhibit high-severity symptoms following the trauma that extinguish over time [70-72]. A similar temporal pattern is also found in animal models of PTSD [73]. There is much interest in studying the immediate or early responses to the trauma, both because those may hint to the way PTSD develops [74] and because it is assumed that, with better understanding of the neural mechanisms of the onset of PTSD, there could be an early window of opportunity for a potential effective intervention that could prevent the development of PTSD [75]. However, the majority of physiological, structural, and molecular changes observed after a trauma are likely to be adaptive and proresilience. PTSD is not defined by the immediate responses to the exposure to the trauma, but is rather a disorder of the lingering symptoms which fail to extinguish. According to the diagnosis criteria in humans, the same symptoms are considered as indicative of PTSD only after 1 month [19]. Accordingly, some researchers focus on behavioral, neurobiological, and physiological alterations which are found long after the exposure to the trauma [76-78].

Clearly, both the early effects of exposure to trauma and its long-term effects should be studied. In addition, the possibility of insidious effects, which develop over time, has been suggested, and should be further explored [76, 79]. It is important, however, to distinguish between findings obtained at different stages after trauma exposure, since those are likely to represent different aspects of the neurobiology of the emergence of PTSD.

\section{Modeling the trauma}

PTSD is associated with the exposure to a significant trauma. This association has led many to consider the trauma as the cause of PTSD. This view, which will be challenged later on (see below and refs. [72, 73, 76, 80]), assumes that exposure to a sufficiently severe trauma would lead to the development of PTSD. The translation of this conception has led in many animal models of PTSD to a focus on the exposure to the trauma. In fact, many models are defined by the type of trauma the animals are exposed to (see Table 2).

\section{The case of classical fear conditioning}

Probably the earliest example was the use of classical fear conditioning. Fear conditioning is induced by exposure to a stressful stimulus, it has long-term impact, the onset of which follows the exposure to the stress, and it is closely associated with the amygdala, a brain structure clearly implicated in PTSD [81]. Indeed, Pavlovian fear conditioning paradigms have been repeatedly proposed to provide important insights into PTSD mechanisms [82, 83]. Undeniably, these have been instrumental in identifying brain regions and local circuits, transmitter systems, and a plethora of molecular factors that are required for or modulate fear learning. As may be expected, these include the typical factors involved in neuronal plasticity, including the mediators of glutamatergic, GABAergic, and neuromodulatory transmission, structural components and modifiers that control the dynamic reorganization of the cytoskeleton, as well as cell-cell and cellmatrix interactions, and various intracellular signaling pathways and regulators of gene expression. A number of excellent reviews are available that has summarized these findings (see, e.g., refs. [84, 85]). Moreover, the involvement of epigenetic modifiers lastingly controlling gene expression has gained increasing attention [86, 87].

The hypothesis behind the employment of fear conditioning paradigms as a model of PTSD was that PTSD is induced by an abnormally strong conditioned fear response. However, while it is clear that fear is abnormally regulated in PTSD, it is not clear whether individuals with PTSD 


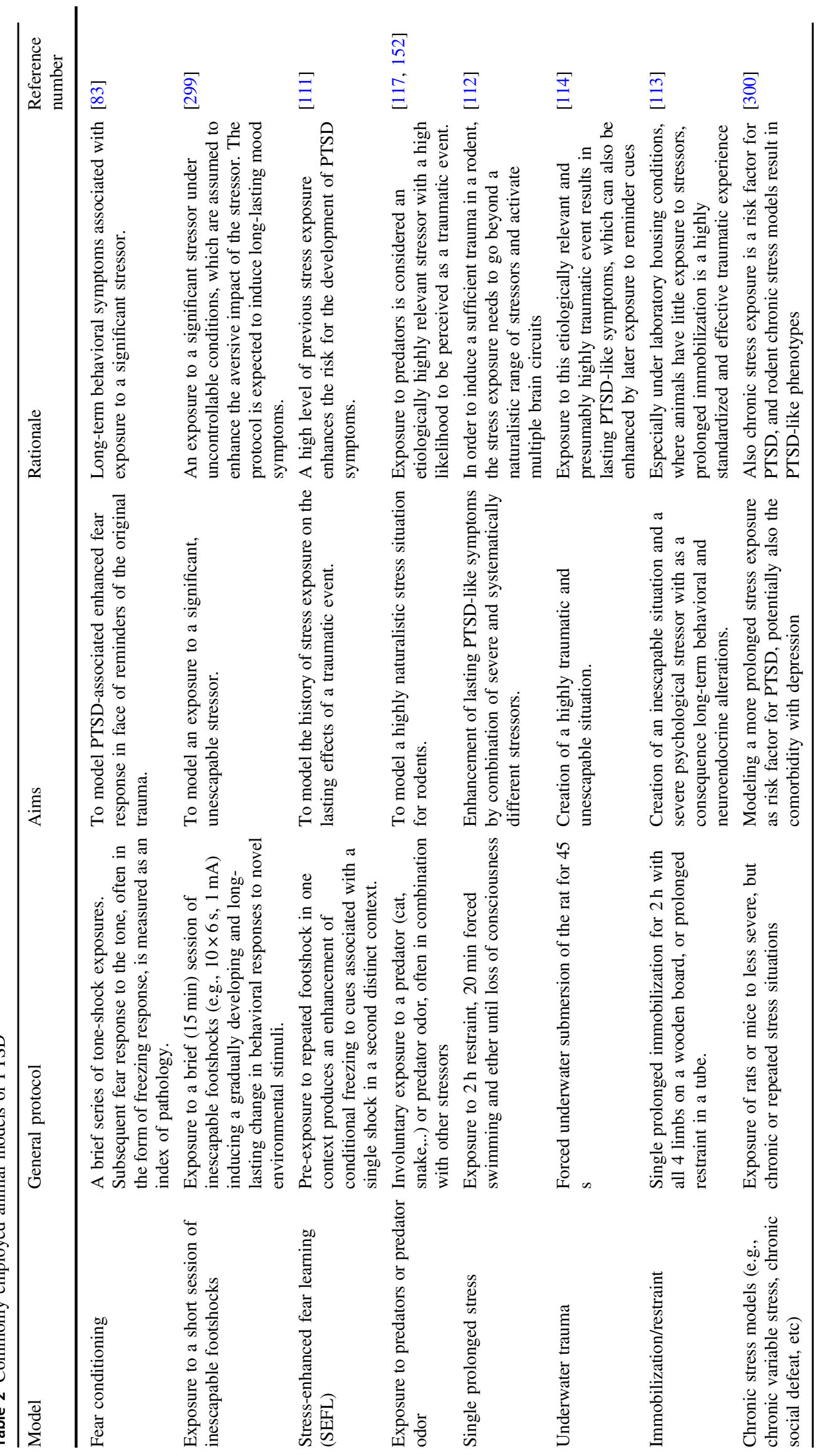


acquire abnormally stronger conditioned fear responses [88]. Classical fear conditioning is a learning process which is normal and critical for animal survival. It is important to note that, when concluding from results of animal experiments using classical fear conditioning regarding potential mechanisms of PTSD, there is in fact an assumption in this approach that the mechanisms underlying PTSD are similar in principle to those of classical fear conditioning, only more intense. While this assumption could be correct, there is also the possibility that PTSD is a result of the collapse of the normal fear responses in the face of severe trauma, and the development of an alternative, pathological process.

Although fear conditioning may not as such be a model of PTSD, its investigation has been informative in identifying molecular and circuitry mechanisms which may be speculated to contribute to the biological base of PTSD. The aim of rodent PTSD models, however, must also be to generate predictions and to identify new potential entry sites for therapy. This is much more difficult to achieve using classical conditioning protocols as we need to cautiously differentiate between the processes that underlie adaptive fear memory formation and those that ultimately lead to pathology. In that respect gene mutations that result in exaggerated fear memories in mice, which are much less frequently observed than those disturbing fear memory formation, may be of interest. Two examples are the null mutant mice of the receptor for interleukin-1 [89] and of the regulator of G-protein signaling-2 [90], and both are indeed recognized as genetic factors in PTSD [91, 92]. Another such example is the glial protein S100B, ablation of which results in increased long-term potentiation and fear memory [93]. While a direct genetic link of S100B to PTSD is still missing, its level was found to increase in the cerebrospinal fluid (CSF) of mice following a combination of maternal separation stress and inescapable footshock in adulthood [94]. In fact, an increasing number of rodent studies is beginning to consider the effect of juvenile adversity, stress sensitization, and other PTSD risk factors on fear memory formation. Thus, the roles of interleukin-1 [95], MR [96], CRF2R [97], or mGluR5 [98] as mediators of stressenhanced fear learning have been demonstrated. Moreover, early-life stress has been shown to impair conditioned fear extinction via changes in $\mathrm{N}$-methyl-D-aspartate receptorextracellular signal-regulated kinase signaling [99] and 5HT1A receptor signaling [100] in the limbic system.

On the other hand, we have previously reported protective gene function of GAD65 haplodeficiency in juvenile stressinduced enhancement of contextual fear memory, although the full mutation recapitulates several PTSD features including generalization and lack of extinction after fear conditioning [101]. This illustrates the often non-linear nature of genotype-phenotype relations in these models and the specificity of phenotypic features. A promising approach for tackling these issues is certainly to target the molecular mechanisms involved in specific aspects of PTSD using optoand pharmacogenetic tools, as done for fear memory incubation [102], fear memory generalization [103, 104], or conditioned fear extinction [105, 106]. Currently, opto- and chemogenetic studies mostly focus on the circuitry identification, but viral knockdown methods have also been introduced in order to dissect the molecular pathways involved in the GABAergic control and synaptic mechanisms of extinction [107-109], or the control of context memory salience [110] in fear conditioning models. The systematic application of these approaches to the critical features of PTSD will shed a new light on the involved processes, and should ultimately be fed into improved and individualized animal models.

\section{Models of the trauma}

Because PTSD is so closely associated with the exposure to a traumatic event, many of the current animal models of PTSD emphasize the type of trauma employed. For example, stress-enhanced fear learning (SEFL) [111] is a rodent model of sensitized responding to threat, in which exposure to a 15-shock stressor non-associatively enhances subsequent fear conditioning training with only a single trial. In another model, single-prolonged stress, proposed by Liberzon et al. [112], animals are exposed to restraint for $2 \mathrm{~h}$, followed by forced swim for $20 \mathrm{~min}$, followed by ether anesthesia. This protocol aims to mimic the assumed massive surge of cortisol, resulting from the exposure to the traumatic event, which is hypothesized to trigger the disorder. Restraint stress or immobilization stress is sometimes used by itself as a model of exposure to stress [113]. Other models of a single exposure to severe stress, which attempted to put emphasis on introducing etiologically relevant stressors, are the 'underwater trauma' model [114], sometimes also termed 'submersion stress' [115], and 'predator/predator odor exposure' [115-117]. Still etiologically relevant but of longer exposure is the model of 'social defeat' [118], in which animals are repeatedly exposed to a social defeat situation over several days.

In all these and similar models, the focus is on the type of trauma the animals are exposed to, under the assumption that, when exposed to a sufficiently severe trauma, animals will develop PTSD-like pathology. There seems to be no need to focus on a single type of exposure, because in humans, markedly different types of trauma are associated with the development of PTSD. It is, however, suggested that different types of trauma may lead to differences in the resultant subtype of PTSD [7]. A variety of animal models with exposure to different kinds of trauma should thus be useful to model the richness of the disorder but attention should be paid to possible differences in outcome between different types of trauma. 
However, there are two important points that should be taken into consideration in respect to the choice of the trauma:

(A) The challenge of ethical considerations. There is no question that animal experimentations should be carried out thoughtfully, and should include ethical considerations. One key ethical principle is to reduce unnecessary suffering of the animals. However, another important principle is to perform experiments in a thoughtful way that would maximize the probability of gaining significant novel findings.

An animal model of PTSD presents an ethical challenge: an effective model is required to involve exposure to a significant trauma, sufficiently significant that it would model the real-life situations associated with PTSD. Emphasizing the principle of reducing suffering leads in some cases to minimizing the level or type of exposure, such that the other principle, that of maximizing the probability of gaining significant novel findings, is compromised. Often researchers choose a stressor that would be more acceptable by the ethical committees, even though it is not certain that such a stressor is really beyond the coping abilities of the animals [119]. Thus, one of the challenges on the way to establish effective animal models of PTSD is to work in cooperation with the ethical committees in order to ensure that the type and severity of the exposure is not compromised such that the relevance of the experiment to PTSD is conceded.

(B) The trauma is not a sufficient condition to induce PTSD. Probably one of the most important aspects to consider in an animal model of PTSD is the fact that most people exposed to trauma do not actually develop PTSD. While in western populations the life-time prevalence of severely stressful events is as high as $75-80 \%$, only about $10 \%$ of this population will suffer from clinically relevant PTSD [120-122]. This proportion of affected versus nonaffected individuals within the exposed population indicates that, in contrast to our intuitive thinking, the exposure to the traumatic experience may be a necessary but not a sufficient condition to induce the disorder. There must be additional factors that determine the outcome of the exposure to the trauma. The fact that a relatively low proportion of exposed individuals eventually develop PTSD is thus a critical factor that should be taken into consideration in animal models of PTSD. There are two ways, which are not mutually exclusive, to incorporate this factor in the animal models: first, to include in the model exposure to risk factors in addition to the exposure to the trauma, and second, to include in the model an individual profiling analysis that would enable identifying the affected individuals within the exposed population (behavioral profiling).

\section{The role of risk factors in animal models of PTSD}

An important question in understanding the neurobiology of PTSD is why some individuals develop PTSD, while others exposed to the same trauma do not. Clearly, some form of a priori susceptibility should be assumed for a trauma to lead to PTSD. Indeed, individual behavioral traits are suggested to predict the response to trauma.

For example, it was found that long-term stress-induced sensitization of behavioral responsivity and somatic pain sensitivity could be predicted by low or high open-field locomotor reactivity [123]. Similarly, physiologic symptoms of analgesia, cognitive deficits, and hyporesponsivity of the HPA axis similar to those observed in human subjects with PTSD were demonstrated in an animal model of congenital learned helpless behavior [124]. High-trait anxiety, which was found to be associated with altered HPA axis activity [125], with differences in mineralocorticoid receptor (MR) expression in the hippocampus and with hippocampus functioning [126], was found to be associated with increased sensitivity to exposure to stress and to increased risk of developing psychopathologies [127]. In accordance with those findings, we could demonstrate that enhanced pretrauma anxiety in a fear-anhedonic and not anxious-only phenotype could predict the progression of posttraumatic anhedonia in a rat model of PTSD [76].

Accordingly, to understand the neural mechanisms of PTSD it is also important to study the mechanisms of such risk factors. Several risk factors have been suggested which may be categorized into background factors, distal life experiences, and proximal factors.

The main suggested background factors involve transgenerational epigenetic effects and genetic background [128-132]. Genetic background though is not sufficient to explain individual differences in sensitivity to stress and trauma, since individual differences are also found within genetically homogeneous populations, such as inbred mice (see, e.g., ref. [133]).

Distal life experiences may interact with a certain genetic background or may be influential enough to produce longlasting alterations in coping abilities later in life. It can be expected that, since from birth to adulthood the brain is going through significant developmental alterations, earlylife adversities would have somewhat different impact if occurring at different developmental stages. Studies should and do differentiate between interventions at different developmental stages, but the impact of distal life adversities has been reported for early-life adversities [134, 135], adversities during childhood [136-139], and during adolescence [140]. Those early-life adversities are suggested to induce alterations in expression profile of critical molecules but also to result in experience-induced epigenetic alterations [141] which can have long-term effects into adulthood [142]. Suggested proximal factors include for example drug and alcohol abuse, sleep deprivation, and illness [143, 144].

Risk factors and the mechanisms by which they hamper the ability to cope with trauma later in life should be studied 
to facilitate development of treatments that would reduce the risk of developing PTSD (see, e.g., refs. [78, 145]). In addition, risk factors should be considered to be included as part of the model of PTSD, both because they reflect the human condition and because they increase the proportion of affected individuals in the sample, which is a clear advantage when aiming to unravel the neurobiological processes involved in psychopathological symptoms. Importantly, exposure to challenges could sometimes build resilience. For example, moderate exposure to early-life adversity has been suggested to increase stress and trauma resilience in adulthood [146, 147] and experimental evidence for this is accumulating in both humans [148] and animal models [149-151].

\section{Behavioral profiling analysis as a critical element of animal models of PTSD}

The individual variability in response to a trauma is evident by the relatively low proportion of individuals who eventually develop PTSD [120-122]. With respect to animal models of PTSD, this individual variability means that referring to the group averaged result, as is typically the practice, would be very inaccurate. It should be expected that, as in humans, within the averaged group, there will be some individuals that, despite being exposed to the traumatic event, have not developed the disorder, or display an intermediate phenotype that could be indicative of an increased risk for trauma-related pathologies in the future. It is thus important to develop ways to differentiate between the affected, intermediate, and the non-affected individuals within the exposed group.

One of the first groups to consider this approach were Cohen et al. [152]. They based the dissociation between 'maladaptive' and 'well-adaptive' responses on the magnitude of the response to the trauma, and differentiating between two extremes using arbitrarily selected cut-off behavioral criteria (CBC) that were based on performance in two successive behavioral tests (elevated plus maze and acoustic startle response tests). Employing this approach, it was possible to demonstrate that, as in humans [72], the prevalence rates of maladaptive responses to trauma dropped over time from $90 \%$ in the acute phase to $25 \%$ enduring/maladaptive response on day 7 , which remained constant over 30 days [73]. This temporal profile, which is consistent in humans and animals, brings up the issue of when the test should be set for the symptoms to be of relevance to PTSD, an issue that will be discussed below.

The CBC approach has been highly productive, yielding a series of findings (see, e.g., refs. [153-155]) which probably could not have been identified otherwise. However, the CBC approach differs from the way diagnosis is done in humans by focusing the analysis on exposed individuals and comparing the performance among them. In order to approximate the diagnosis procedure in humans more closely, we have developed a variation of the $\mathrm{CBC}$, termed 'behavioral profiling' [76, $77,139,156]$. Behavioral profiling is based on referring to the performance of a control, non-exposed group as defining the norm. The performance of this group in a carefully selected test battery is first analyzed, and for each behavioral measurement cut-off values are defined in a way which leaves $85 \%$ of the control population within the norm values. Notably, several behavioral measurements are used. This is done prior to examining the exposed groups. Only after the cut-off values are defined, an analysis of all animals in all groups is carried out. Importantly, in order for an animal to be defined as affected, it has to fall out of the defined norm in several parameters, rather than just one (e.g., 4 out of 6 or 5 out of 8 ). This way, similarly to humans, control animals may have one or two parameters out of the norm, and still not be defined as affected.

It was important to demonstrate that differentiating animals to 'affected' and 'non-affected' based on the behavioral parameters in this analysis had functional significance. It was indeed demonstrated that in response to a reminder of the trauma, the map of brain activation was significantly different between animals that were exposed to the trauma and developed symptoms (exposed-affected) and those that were exposed to the same trauma but did not develop significant symptoms (exposed-non-affected) [76].

The importance of employing the behavioral profiling approach became clearly evident in another recent study, where we examined GABAergic changes related to PTSD, focusing on alterations in the expression of $\alpha$ subunits of the $\mathrm{GABA}_{\mathrm{A}}$ receptor in several brain areas. Animals were exposed to trauma, and 4 weeks later were tested in a battery of tests which enabled dissociating the animals to affected and non-affected individuals. Examining group means, a significant elevation in the expression of the $\alpha 1$ subunit was found in the amygdala and hippocampus of the exposed group. Because on average the exposed group exhibited significantly higher levels of symptoms, it was tempting to conclude that the elevation in expression levels of the $\alpha 1$ subunit is associated with the pathology. Such a conclusion would have led to focusing efforts on reducing the expression of $\alpha 1$ as a protective measure. However, when reanalyzing the same data with the behavioral profiling approach, differentiating between affected and non-affected individuals within the exposed group, it was found that the elevation in expression levels of the $\alpha 1$ subunit stemmed from the exposed, non-affected individuals. This surprising finding indicates that the elevation in expression levels of $\alpha 1$ is associated with resilience rather than with the pathology [77].

It is advisable to combine the incorporation of risk factors and behavioral profiling analysis. Combining these approaches may help evaluating potential risk factors, both in terms of symptom severity and in terms of increasing the 
proportion of affected individuals within the traumaexposed group. An increase in the proportion of affected individuals is suggested to be a more sensitive measure for the contribution of risk factors than the intensity of symptoms $[77,156]$.

\section{Sex differences}

PTSD is considered to be more prevalent in women than in men [157-161] to the extent that some reviews refer to sex as a risk factor for PTSD [157, 162]. Differences between the way that the gonadal hormones testosterone or estrogen interact with the HPA axis or modulate hippocampal functioning, reported both in humans and in animal models, have been suggested as contributing to this bias [163-166].

Nevertheless, this notion is debatable, with some surveys failing to demonstrate such sex-related bias (see, e.g., refs [167-169]). It is not trivial to develop a conclusive picture, in part because the types of trauma males and females are more often exposed to are different, and because social stigma and support associated with different traumas are not similar for men and women [160, 170]. In addition, it may be that the prevalence of expression of certain symptoms is different between males and females. It has been suggested that the assumed sex difference in the prevalence of PTSD may be explained, at least in part, by the choice of symptoms used for the diagnosis of the disorder which may lead to females being more likely than males to meet current criteria for PTSD (see, e.g.,refs. [171-174]).

Animal models reflect this complexity of sex differences [170, 175-177]. Male and female rodents respond differently to stress and trauma $[170,175,176]$, and to risk factors associated with the trauma, such as prepubertal, or juvenile pre-exposure to stress $[156,177,178]$. On the other hand, it is important to note that when presented with a relevant trauma and relevant risk factors, both males and females may develop PTSD-like symptoms [156, 179]. Nevertheless, as in humans, the main pathological symptoms presented by males may differ from those presented by females [156]. For example, in the study of Horovitz et al. [156], only males exhibited impairment in the two-way shuttle avoidance task, only females exhibited anhedonia, but both sexs exhibited reduced exploratory behavior. Using only one behavioral test would have inevitably led to a wrong conclusion regarding stress vulnerability and sex differences.

\section{Posttraumatic stress, posttraumatic depression, and comorbidity}

Comorbidity of mood and anxiety disorders is the rule rather than the exception [180-183], and this is not different when referring specifically to PTSD [168, 184]. Whether it is only comorbidity or should PTSD, as suggested
[185-187], be sub-divided to posttraumatic stress disorder and posttraumatic depression is still debatable. In any case, there is a growing understanding that PTSD, which used to be considered an anxiety disorder (DSM4) [188], is a more complex disorder, in which patients exhibit a mixture of symptoms of anxiety, mood, and cognition [19].

The behavioral profiling analysis approach can be adopted to assess anxiety, depressive, and cognitive symptoms. Exploiting this possibility reveals that similar complexity also exists in rodents [76, 156, 189-194]. For example, Tsoory et al. [190] demonstrated that, among the exposedaffected individuals, some exhibited more anxious symptoms, whereas others exhibited more depressive symptoms. Developing this further, Ritov et al. [76] demonstrated that such categorization of the exposed-affected individuals based on behavioral symptoms was associated with correlative differences in maps of neural activation, indicating that the behavioral profiling has functional implications which are reflected in neural processing [76].

The behavioral profiling approach also corresponds with the concern raised in recent years in psychiatry regarding the diagnostic criteria as determined by DSM categories $[195,196]$ in the sense that, as long as there is no 'biological signature' to a disorder, our current ability to define a symptom as representing anxiety, mood, motivation, or memory is limited. Referring to the performance of a control, non-exposed group as defining the norm does not require defining the deviation from the norm as an anxiety or mood symptom. It is an indication for an 'abnormal' behavior which awaits further classification based on physiological, neuronal, and pharmacological findings.

\section{Susceptibility and resilience in the face of trauma}

The fact that exposure to trauma leads to PTSD only in some of the exposed individuals suggests that, while some are susceptible, others are somehow resilient to the impact of the trauma. Understanding the neurobiology of PTSD involves the understanding of mechanisms of susceptibility and resilience. Furthermore, the realization that resilience is a possibility has opened the way to the possibility of interventions aiming at prevention of PTSD and of treatments aiming at promoting resilience (see, e.g., refs. [145, 197]).

Exposure of animals to stress, and much more so, exposure to traumatic stress results in many epigenetic, gene expression, and biochemical alterations and resultant alterations in activity in many brain areas (see, e.g., refs. [76, 198-202]). Typically, such changes are assumed to be associated with the pathology. However, findings suggest that resilience is an active process in which the neurons make active efforts to cope with the challenge (see, e.g., refs. [76, 139, 155, 203, 204]). Differentiating between those alterations related to the pathology and 
those related to resilience is far from being a trivial challenge. Behavioral profiling, which enables differentiating between exposed-affected and exposed-nonaffected individuals, is a valuable tool that may help differentiating between resilience-related and pathologyrelated targets [77]. Importantly, it would be feasible to apply treatments that either increase resilience in an individual or alternatively reduce susceptibility, and the underlying mechanisms could be very distinct. As treatment of individuals before any trauma exposure is not feasible, though, it remains to be seen if the identified resilience/susceptibility mechanisms can also be utilized for treatment interventions.

\section{Summary}

Recent years have seen growing criticism of animal models of psychiatric disorders in general and of animal models of PTSD in particular [15-17, 66, 69], up to the point of questioning the ability of such models to contribute to our understanding of the neurobiology of these disorders (e.g., ref. [15]). However, cumulative results from recent years indicate that animal models of PTSD are not only invaluable in understanding basic mechanisms of fear and memory processes, but are also able to capture the human complexity and differences of sensitivity to risk factors and to stressors, as well as the differences in the main resultant symptoms. However, in order for the models to be sensitive to such individual differences and to variations between sexes, the choice of risk factors, of the type of trauma, and of the behavioral measures of symptoms should be carefully selected before drawing conclusions. Importantly, moving the field towards a behavioral profiling analysis approach, which takes into consideration individual differences, is critical for being able to relate behavioral symptoms with their neural correlates and for establishing effective drug development and drug testing platforms. These novel developments in the way PTSD is modeled in animals, reviewed here,

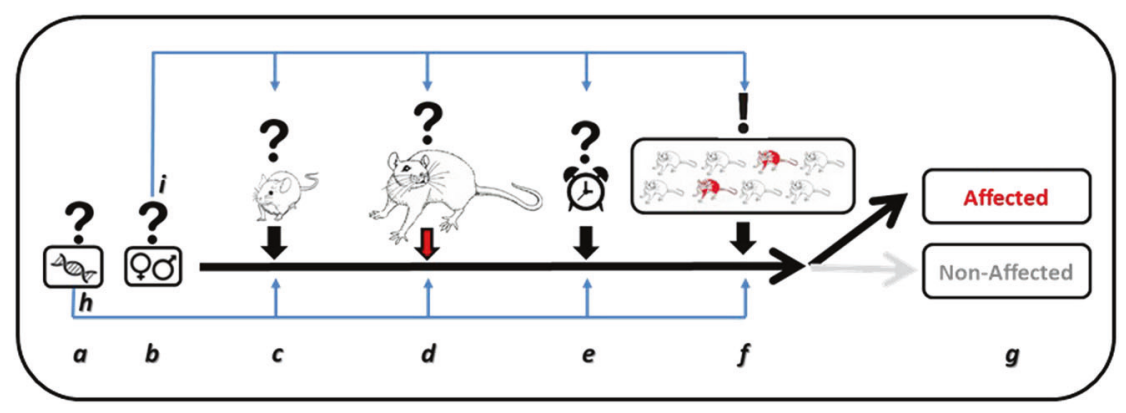

Fig. 1 Guiding principles for selecting an animal model of PTSD. There is no single animal model of PTSD which as such is more adequate than others. Different models have their pros and cons. There are, however, several principles which are, in view of the authors, critical and should be incorporated in any model in order to increase the ecological validity of the models and their relevance to the human psychopathology. a Humans exposed to trauma are of heterogeneous genetic background. It should be natural to select outbred strains with a similar heterogeneous genetic background. Selecting an inbred line should be considered as a manipulation which defines the scope of the outcome of the study. As is indicated by the pale blue arrowed line (h), the genetic disposition may mediate effects at multiple levels, i.e., at the juvenile adversity, the trauma perception, and/or the individual outcome. b Males and females are sensitive to stress and trauma in different ways. The preference should be to examine both males and females. However, it should be borne in mind that specific manipulations may affect more either males or females. Likewise, males and females may differ in the behavioral aspects which are affected and thus different behavioral tests may be required in order to identify affected males or females. As is indicated by the pale blue arrowed line (i), sex differences may mediate effects at multiple levels, i.e., at the juvenile adversity, the trauma perception, and/or the individual outcome. c Most individuals exposed to trauma will not develop PTSD, indicating that the trauma will only be effective if it interacts with some additional pre-disposing factors. Studying the neurobiology of predisposing factors is thus a fundamental part of understanding the neurobiology of PTSD. Adding potential risk factors and examining their contribution should be considered, regardless of which trauma model is employed. d As is indicated in the text, there is no right or wrong with regards to which trauma should be employed in animal models of PTSD. Also, in humans different types of trauma may lead to the development of the disorder in some individuals. However, the choice of trauma and its parameters should be carefully considered and described, since this choice defines the relevance of the outcome of the study to exposure of similar nature in humans. Furthermore, researchers should address the question of the assumed severity of the traumatic experience. A clearer dissociation between stressful experiences (which are within the coping abilities of the animal) and traumatic experiences (which are beyond the coping abilities of the animal) is needed and should become part of the discussion of any study. $\mathbf{e}$ The age of exposure to trauma as well as the time after exposure for testing the impact of the exposure are important factors to consider. There is no right or wrong here but those choices define the relevance of the outcome of the study to exposure of similar nature and to the stage of evaluation in humans. f Because only some individuals exposed to a trauma will develop psychopathology it is critical to move away from analyzing the averages of the exposed and non-exposed groups. Instead, a more individual characterization of each animal as being pathologically affected or not is required. Towards that end, it seems important to aim for examining animals over batteries of tests that cover several behavioral faculties, in order to achieve a more reliable profiling of the individual animals. $\mathbf{g}$ Individual profiling of the animals could then be translated into defining individual animals as affected or non-affected, in a similar way to diagnosis in humans. With that type of analysis, effects of drugs can be examined as the impact of the proportion of affected/non-affected individuals, rather than on the averaged severity of specific symptoms 
indicate that, with an appropriate shift of practice, animal models of PTSD are a valuable research tool for promoting our understanding of the neurobiology of PTSD (see Fig. 1 for summary).

Recently developed technology has further paved the way for this approach with (a) the rapid development of new chemo-optogenetic tools that allow us to target the intracellular localization activity of particular molecules as well as gene expression in defined cells and circuits [205, 206], (b) the evolution of CRISPR/Cas (Clustered Regularly Interspaced Short Palindromic Repeats/CRISPR-associated 9) technology which allows for the rapid generation of mutant mice and rats and base-specific engineering of any chosen gene in somatic target cells [207, 208] and single cell transcriptome analytics [209] providing unprecedented opportunities to examine the dynamics of activity and the molecular characteristics of such circuitries. Furthermore, the growing understanding of neural pathways involved in fear and PTSD is already suggested to be translated to new treatment approaches, such as DBS [210]. These methodologies should now be implemented in improved animal models of PTSD.

Acknowledgements The authors wish to thank the long list of students, postdocs, and colleagues, many of whom appear in the reference list, who were part of this long journey and who contributed to the insights about PTSD and modeling it. This work was supported by research grant no. 3-13563 from the State of Israel Ministry of Science, Technology, \& Space to GR-L, and by a DFG grant STO 488/6-1 to OS and GR-L.

\section{Compliance with ethical standards}

Conflict of interest The authors declare that they have no conflict of interest.

Open Access This article is licensed under a Creative Commons Attribution 4.0 International License, which permits use, sharing, adaptation, distribution and reproduction in any medium or format, as long as you give appropriate credit to the original author(s) and the source, provide a link to the Creative Commons license, and indicate if changes were made. The images or other third party material in this article are included in the article's Creative Commons license, unless indicated otherwise in a credit line to the material. If material is not included in the article's Creative Commons license and your intended use is not permitted by statutory regulation or exceeds the permitted use, you will need to obtain permission directly from the copyright holder. To view a copy of this license, visit http://creativecommons. org/licenses/by/4.0/.

\section{References}

1. Crocq MA, Crocq L. From shell shock and war neurosis to posttraumatic stress disorder: a history of psychotraumatology. Dialog Clin Neurosci. 2000;2:47-55.

2. Karam EG, Andrews G, Bromet E, Petukhova M, Ruscio AM, Salamoun M, et al. The role of Criterion A2 in the DSM-IV diagnosis of post-traumatic stress disorder. Biol Psychiatry. 2009;68:465-73.

3. Steel Z, Chey T, Silove D, Marnane C, Bryant RA, van Ommeren M. Association of torture and other potentially traumatic events with mental health outcomes among populations exposed to mass conflict and displacement: a systematic review and meta-analysis. JAMA. 2009;302:537-49.

4. Brunello N, Davidson JR, Deahl M, Kessler RC, Mendlewicz J, Racagni G, et al. Posttraumatic stress disorder: diagnosis and epidemiology, comorbidity and social consequences, biology and treatment. Neuropsychobiology. 2001;43:150-62.

5. Van der Kolk BA, Pelcovitz D, Roth S, Mandel FS, McFarlane A, Herman JL. Dissociation, somatization, and affect dysregulation: the complexity of adaptation to trauma. Am J Psychiatry. 1997;153:83-93.

6. Guina J, Baker M, Stinson K, Maust J, Coles J, Broderick P. Should posttraumatic stress be a disorder or a specifier? Towards improved nosology within the DSM categorical classification system. Curr Psychiatry Rep. 2017;19:66.

7. Stein JY, Wilmot DV, Solomon Z. Does one size fit all? Nosological, clinical, and scientific implications of variations in PTSD Criterion A. J Anxiety Disord. 2016;43:106-17.

8. Mello PG, Silva GR, Donat JC, Kristensen CH. An update on the efficacy of cognitive-behavioral therapy, cognitive therapy, and exposure therapy for posttraumatic stress disorder. Int J Psychiatry Med. 2013;46:339-57.

9. Kaczkurkin AN, Foa EB. Cognitive-behavioral therapy for anxiety disorders: an update on the empirical evidence. Dialog Clin Neurosci. 2015;17:337-46.

10. Kar N. Cognitive behavioral therapy for the treatment of posttraumatic stress disorder: a review. Neuropsychiatr Dis Treat. 2011;7:167-81.

11. Kozaric-Kovacic D. Psychopharmacotherapy of posttraumatic stress disorder. Croat Med J. 2008;49:459-75.

12. Ragen BJ, Seidel J, Chollak C, Pietrzak RH, Neumeister A. Investigational drugs under development for the treatment of PTSD. Expert Opin Investig Drugs. 2015;24:659-72.

13. Murrough JW, Charney DS. Is there anything really novel on the antidepressant horizon? Curr Psychiatry Rep. 2012;14:643-9.

14. Hoskins M, Pearce J, Bethell A, Dankova L, Barbui C, Tol WA, et al. Pharmacotherapy for post-traumatic stress disorder: systematic review and meta-analysis. $\mathrm{Br} \mathrm{J}$ Psychiatry. 2015; 206:93-100.

15. Papassotiropoulos A, de Quervain DJ. Failed drug discovery in psychiatry: time for human genome-guided solutions. Trends Cogn Sci. 2015;19:183-7.

16. Insel TR. Next-generation treatments for mental disorders. Sci Transl Med. 2012;4:155ps19.

17. Abbott A. Novartis to shut brain research facility. Nature. 2011;480:161-2.

18. Shalev A, Liberzon I, Marmar C. Post-Traumatic Stress Disorder. N Engl J Med. 2017;376:2459-69.

19. American Psychiatric Association. Diagnostic and statistical manual of mental disorders (DSM- $\left.5^{\circledR}\right)$. American Psychiatric Pub, Arlington, VA, US, 2013.

20. Insel T, Cuthbert B, Garvey M, Heinssen R, Pine DS, Quinn K, et al. Research domain criteria (RDoC): toward a new classification framework for research on mental disorders. Am J Psychiatry. 2010;167:748-51.

21. Morris SE, Cuthbert BN. Research Domain Criteria: cognitive systems, neural circuits, and dimensions of behavior. Dialog Clin Neurosci. 2012;14:29-37.

22. Schmidt U, Vermetten E. Integrating NIMH research domain criteria (RDoC) into PTSD research. In: Vermetten E, Baker D, Risbrough V, editors. Current topics in behavioral neurosciences. Berlin, Heidelberg: Springer; 2017. p. 1-23. 
23. Afifi TO, Asmundson GJG, Taylor S, Jang KL. The role of genes and environment on trauma exposure and posttraumatic stress disorder symptoms: a review of twin studies. Clin Psych Rev. 2010;30:101-12.

24. Hyde CL, Nagle MW, Tian C, Chen X, Paciga SA, Wendland JR. et al.Identification of 15 genetic loci associated with risk of major depression in individuals of European descent.Nat Gen. 2016;48:1031-6.

25. Almli LM, Fani N, Smith AK, Ressler KJ. Genetic approaches to understanding post-traumatic stress disorder. Int $\mathrm{J}$ Neuropsychopharmacol. 2014;17:355-70.

26. Logue MW, Amstadter AB, Baker DG, Duncan L, Koenen KC, Liberzon I, et al. The Psychiatric Genomics Consortium Posttraumatic Stress Disorder Workgroup: posttraumatic stress disorder enters the age of large-scale genomic collaboration. Neuropsychopharmacology. 2015;40:2287-97.

27. Yehuda R, Golier JA, Halligan SL, Meaney M, Bierer LM. The ACTH response to dexamethasone in PTSD. Am J Psychiatry. 2004;161:1397-403.

28. Daskalakis NP, Lehrner A, Yehuda R. Endocrine aspects of posttraumatic stress disorder and implications for diagnosis and treatment. Endocrinol Metab Clin North Am. 2013;42:503-13.

29. Castro-Vale I, van Rossum EFC, Machado JC, Mota-Cardoso R, Carvalho D. Genetics of glucocorticoid regulation and posttraumatic stress disorder: What do we know? Neurosci Biobehav Rev. 2016;63:143-57.

30. Schmidt MV, Paez-Pereda M, Holsboer F, Hausch F. The prospect of FKBP51 as a drug target. ChemMedChem. 2012;7:1351-9.

31. Klengel T, Mehta D, Anacker C, Rex-Haffner M, Pruessner JC, Pariante CM, et al. Allele-specific FKBP5 DNA demethylation mediates gene-childhood trauma interactions. Nat Neurosci. 2013;16:33-41.

32. Klengel T, Binder EB. Epigenetics of stress-related psychiatric disorders and gene*environment interactions. Neuron. 2015;86:1343-57.

33. Binder EB, Bradley RG, Liu W, Epstein MP, Deveau TC, Mercer KB, et al. Association of FKBP5 polymorphisms and childhood abuse with risk of posttraumatic stress disorder symptoms in adults. JAMA. 2008;299:1291-305.

34. Boscarino JA, Erlich PM, Hoffman SN, Rukstalis M, Stewart WF. Association of FKBP5, COMT and CHRNA5 polymorphisms with PTSD among outpatients at risk for PTSD. Psychiatry Res. 2011;188:173-4.

35. Watkins LE, Han S, Harpaz-Rotem I, Mota NP, Southwick SM, Krystal JH, et al. FKBP5 polymorphisms, childhood abuse, and PTSD symptoms: results from the National Health and Resilience in Veterans Study. Psychoneuroendocrinology. 2016;69:98-105.

36. Xie P, Kranzler HR, Poling J, Stein MB, Anton RF, Farrer LA, et al. Interaction of FKBP5 with childhood adversity on risk for post-traumatic stress disorder. Neuropsychopharmacology. 2010;35:1684-92.

37. Gaali S, Kirschner A, Cuboni S, Hartmann J, Kozany C, Balsevich G, et al. Selective inhibitors of the FK506-binding protein 51 by induced fit. Nat Chem Biol. 2015;11:33-37.

38. Hartmann J, Wagner KV, Gaali S, Kirschner A, Kozany C, Rühter G, et al. Pharmacological inhibition of the psychiatric risk factor FKBP51 has anxiolytic properties. J Neurosci. 2015;35:9007-16

39. Zhang L, Li XX, Hu XZ. Post-traumatic stress disorder risk and brain-derived neurotrophic factor Val66Met. World J Psychiatry. 2016;206:1-6.

40. Nestler EJ, Barrot M, DiLeone RJ, Eisch AJ, Gold SJ, Monteggia LM. Neurobiology of depression. Neuron. 2002;34: $13-25$.
41. Grabe HJr, Spitzer C, Schwahn C, Marcinek A, Frahnow A, Barnow S, et al. Serotonin transporter gene (SLC6A4) promoter polymorphisms and the susceptibility to posttraumatic stress disorder in the general population. Am $\mathrm{J}$ Psychiatry. 2009;166:926-33.

42. Li L, Bao Y, He S, Wang G, Guan Y, Ma D, et al. The association between genetic variants in the dopaminergic system and posttraumatic stress disorder: a meta-analysis. Medicine (Baltimore). 2016;95:e3074.

43. Gressier F, Calati R, Balestri M, Marsano A, Alberti S, Antypa $\mathrm{N}$. The 5-HTTLPR polymorphism and posttraumatic stress disorder: a meta-analysis. J Trauma Stress. 2013;26:645-53.

44. Pitman RK, Rasmusson AM, Koenen KC, Shin LM, Orr SP, Gilbertson MW, et al. Biological studies of post-traumatic stress disorder. Nat Rev Neurosci. 2012;13:769-87.

45. Bennett MR, Hatton SN, Lagopoulos J. Stress, trauma and PTSD: translational insights into the core synaptic circuitry and its modulation. Brain Struct Funct. 2016;221:2401-26.

46. Green CR, Corsi-Travali S, Neumeister A. The role of BDNFTrkB signaling in the pathogenesis of PTSD. J Depress Anxiety. 2013;2013(S4):006.

47. Peters J, Dieppa-Perea LM, Melendez LM, Quirk GJ. Induction of fear extinction with hippocampal-infralimbic BDNF. Science. 2010;328:1288-90.

48. Kozlovsky N, Matar MA, Kaplan Z, Kotler M, Zohar J, Cohen $\mathrm{H}$. Long-term down-regulation of BDNF mRNA in rat hippocampal CA1 subregion correlates with PTSD-like behavioural stress response. Int $\mathrm{J}$ Neuropsychopharmacol. 2007;10: 741-58.

49. Takei S, Morinobu S, Yamamoto S, Fuchikami M, Matsumoto T, Yamawaki S. Enhanced hippocampal BDNF/TrkB signaling in response to fear conditioning in an animal model of posttraumatic stress disorder. J Psychiatr Res. 2011;45:460-8.

50. Yu H, Wang Y, Pattwell S, Jing D, Liu T, Zhang Y, et al. Variant BDNF Val66Met polymorphism affects extinction of conditioned aversive memory. J Neurosci. 2009;29:4056-64.

51. Kazim SF, Iqbal K. Neurotrophic factor small-molecule mimetics mediated neuroregeneration and synaptic repair: emerging therapeutic modality for Alzheimer's disease. Mol Neurodegener. 2016;11:50.

52. Daskalakis NP, Cohen H, Cai G, Buxbaum JD, Yehuda R. Expression profiling associates blood and brain glucocorticoid receptor signaling with trauma-related individual differences in both sexes. Proc Natl Acad Sci USA. 2014;111:13529-34.

53. Sawamura T, Klengel T, Armario A, Jovanovic T, Norrholm SD, Ressler KJ, et al. Dexamethasone treatment leads to enhanced fear extinction and dynamic Fkbp5 regulation in amygdala. Neuropsychopharmacology. 2016;41:832-46.

54. Patel S, Hill MN, Cheer JF, Wotjak CT, Holmes A. The endocannabinoid system as a target for novel anxiolytic drugs. Neurosci Biobehav Rev. 2017;76:56-66.

55. Matar MA, Zohar J, Cohen H. Translationally relevant modeling of PTSD in rodents. Cell Tissue Res. 2013;354:127-39.

56. Daskalakis NP, Yehuda R, Diamond DM. Animal models in translational studies of PTSD. Psychoneuroendocrinology. 2013;38:1895-911.

57. Borghans B, Homberg JR. Animal models for posttraumatic stress disorder: an overview of what is used in research. World $\mathrm{J}$ Psychiatry. 2015;5:387-96.

58. Schöner J, Heinz A, Endres M, Gertz K, Kronenberg G. Posttraumatic stress disorder and beyond: an overview of rodent stress models. J Cell Mol Med. 2017;21:2248-56.

59. Nestler EJ, Hyman SE. Animal models of neuropsychiatric disorders. Nat Neurosci. 2010;13:1161-9.

60. Hyman SE. Psychiatric Drug Development: Diagnosing a Crisis. Cerebrum: The Dana Forum on Brain Science, 2013: 5. 
61. Brady KT. Posttraumatic stress disorder and comorbidity: recognizing the many faces of PTSD. J Clin Psychiatry. 1997;58 Suppl 9:12-5.

62. Conway KP, Compton W, Stinson FS, Grant BF. Lifetime comorbidity of DSM-IV mood and anxiety disorders and specific drug use disorders: results from the National Epidemiologic Survey on Alcohol and Related Conditions. J Clin Psychiatry. 2006;67:247-57.

63. Flory JD, Yehuda R. Comorbidity between post-traumatic stress disorder and major depressive disorder: alternative explanations and treatment considerations. Dialog Clin Neurosci. 2015;17:141-50.

64. Willner P. The validity of animal models of depression. Psychopharmacology (Berlin). 1984;83:1-16.

65. Van der Staay FJ, Arndt SS, Nordquist RE. Evaluation of animal models of neurobehavioral disorders. Behav Brain Funct. 2009;5:11-33.

66. Finsterwald C, Steinmetz AB, Travaglia A, Alberini CM. From memory impairment to posttraumatic stress disorder-like phenotypes: the critical role of an unpredictable second traumatic experience. J Neurosci. 2015;35:15903-15.

67. Desmedt A, Marighetto A, Piazza PV. Abnormal fear memory as a model for posttraumatic stress disorder. Biol Psychiatry. 2015;78:290-7.

68. Deslauriers J, Toth M, Der-Avakian A, Risbrough VB. Current status of animal models of posttraumatic stress disorder: behavioral and biological phenotypes, and future challenges in improving translation. Biol Psychiatry. 2018;83:895-907.

69. Hyman SE. Revolution stalled. Sci Transl Med. 2012;4:155cm11.

70. Rothbaum BO, Foa EB, Riggs DS, Murdock T, Walsh W. A prospective examination of posttraumatic stress disorder in rape victims. J Trauma Stress. 1992;5:455-75.

71. Yehuda R, McFarlane AC, Shalev AY. Predicting the development of posttraumatic stress disorder from the acute response to a traumatic event. Biol Psychiatry. 1998;44:1305-13.

72. Bonanno GA, Mancini AD. The human capacity to thrive in the face of potential trauma. Pediatrics. 2008;121:369-75.

73. Cohen H, Zohar J, Matar MA, Zeev K, Loewenthal U, RichterLevin G. Setting apart the affected: the use of behavioral criteria in animal models of post-traumatic stress disorder. Neuropsychopharmacology. 2004;29:1962-70.

74. Ardi Z, Ritov G, Lucas M, Richter-Levin G. The effects of a reminder of underwater trauma on behaviour and memoryrelated mechanisms in the rat dentate gyrus. Int $\mathrm{J}$ Neuropsychopharmacol. 2014; 17:571-80.

75. Carmi L, Fostick L, Burshtein S, Cwikel-Hamzany S, Zohar J. PTSD treatment in light of DSM-5 and the "golden hours" concept. CNS Spectr. 2016;21:279-82.

76. Ritov G, Boltyansky B, Richter-Levin G. A novel approach to PTSD modeling in rats reveals alternating patterns of limbic activity in different types of stress reaction. Mol Psychiatry. 2016;21:630-41.

77. Ardi Z, Albrecht A, Richter-Levin A, Saha R, Richter-Levin G. Behavioral profiling as a translational approach in an animal model of posttraumatic stress disorder. Neurobiol Dis. 2016;88:139-47.

78. Ritov G, Richter-Levin G. Pre-trauma methylphenidate in rats reduces PTSD-like reactions one month later. Transl Psychiatry. 2017;7:e1000

79. Wang W, Liu Y, Zheng H, Wang HN, Jin X, Chen YC, et al. A modified single-prolonged stress model for post-traumatic stress disorder. Neurosci Lett. 2008;441:237-41.

80. Yehuda R, LeDoux J. Response variation following trauma: a translational neuroscience approach to understanding PTSD. Neuron. 2007;56:19-32.
81. Ledoux JE. Emotion circuits in the brain. Annu Rev Neurosci. 2000;23:155-84.

82. Careaga MBL, Girardi CEN, Suchecki D. Understanding posttraumatic stress disorder through fear conditioning, extinction and reconsolidation. Neurosci Biobehav Rev. 2016;71:48-57.

83. Mahan AL, Ressler KJ. Fear conditioning, synaptic plasticity and the amygdala: implications for posttraumatic stress disorder. Trends Neurosci. 2012;35:24-35.

84. Johansen JP, Cain CK, Ostroff LE, LeDoux JE. Molecular mechanisms of fear learning and memory. Cell. 2011; 147:509-24.

85. Lamprecht $\mathrm{R}$. The role of actin cytoskeleton in memory formation in amygdala. Front Mol Neurosci. 2016;9:23.

86. Kwapis JL, Wood MA. Epigenetic mechanisms in fear conditioning: implications for treating post-traumatic stress disorder. Trends Neurosci. 2014;37:706-20.

87. Sweatt JD. Experience-dependent epigenetic modifications in the central nervous system. Biol Psychiatry. 2009;65:191-7.

88. Goswami S, Rodríguez-Sierra O, Cascardi M, Paré D. Animal models of post-traumatic stress disorder: face validity. Front Neurosci. 2013;7:89.

89. Koo JW, Duman RS. Interleukin-1 receptor null mutant mice show decreased anxiety-like behavior and enhanced fear memory. Neurosci Lett. 2009;456:39-43.

90. Raab A, Popp S, Lesch KP, Lohse MJ, Fischer M, Deckert J. et al. Increased fear learning, spatial learning as well as neophobia in Rgs2-/- mice. Genes Brain Behav. 2017;17:e12420

91. Amstadter AB, Koenen KC, Ruggiero KJ, Acierno R, Galea S, Kilpatrick DG, et al. Variant in RGS2 moderates posttraumatic stress symptoms following potentially traumatic event exposure. J Anxiety Disord. 2009;23:369-73.

92. Hovhannisyan L, Stepanyan A, Arakelyan A. Genetic variability of interleukin-1 beta as prospective factor from developing posttraumatic stress disorder. Immunogenetics. 2017;69:703-8.

93. Nishiyama H, Knopfel T, Endo S, Itohara S. Glial protein S100B modulates long-term neuronal synaptic plasticity. Proc Natl Acad Sci USA. 2002;99:4037-42.

94. Diehl LA, Silveira PP, Leite MC, Crema LM, Portella AK, Billodre $\mathrm{MN}$, et al. Long lasting sex-specific effects upon behavior and S100b levels after maternal separation and exposure to a model of post-traumatic stress disorder in rats. Brain Res. 2007;1144:107-16.

95. Jones ME, Lebonville CL, Paniccia JE, Balentine ME, Reissner KJ, Lysle DT. Hippocampal interleukin-1 mediates stressenhanced fear learning: A potential role for astrocyte-derived interleukin-1 $\beta$. Brain Behav Immun. 2018;67:355-63.

96. Vogel S, Klumpers F, Kroes MC, Oplaat KT, Krugers HJ, Oitzl MS, et al. A stress-induced shift from trace to delay conditioning depends on the mineralocorticoid receptor. Biol Psychiatry. 2015;78:830-9.

97. Sananbenesi F, Fischer A, Schrick C, Spiess J, Radulovic J. Mitogen-activated protein kinase signaling in the hippocampus and its modulation by corticotropin-releasing factor receptor 2: a possible link between stress and fear memory. J Neurosci. 2003;23:11436-43.

98. Tronson NC, Guzman YF, Guedea AL, Huh KH, Gao C, Schwarz MK, et al. Metabotropic glutamate receptor 5/Homer interactions underlie stress effects on fear. Biol Psychiatry. 2010;68:1007-15.

99. Ishikawa S, Saito Y, Yanagawa Y, Otani S, Hiraide S, Shimamura K, et al. Early postnatal stress alters extracellular signalregulated kinase signaling in the corticolimbic system modulating emotional circuitry in adult rats. Eur $\mathbf{J}$ Neurosci. 2012;35:135-45.

100. Koseki H, Matsumoto M, Togashi H, Miura Y, Fukushima K, Yoshioka M. Alteration of synaptic transmission in the 
hippocampal-mPFC pathway during extinction trials of contextdependent fear memory in juvenile rat stress models. Synapse. 2009;63:805-13.

101. Müller I, Çalışkan G, Stork O. The GAD65 knock out mouse - a model for GABAergic processes in fear- and stress-induced psychopathology. Genes Brain Behav. 2015;14:37-45.

102. Tsuda MC, Yeung HM, Kuo J, Usdin TB. Incubation of fear is regulated by TIP39 peptide signaling in the medial nucleus of the amygdala. J Neurosci. 2015;35:12152-61.

103. Xu W, Südhof TC. A neural circuit for memory specificity and generalization. Science. 2013;339:1290-5.

104. Zhou H, Xiong GJ, Jing L, Song NN, Pu DL, Tang X, et al. The interhemispheric CA1 circuit governs rapid generalisation but not fear memory. Nat Commun. 2017;8:2190.

105. Jasnow AM, Ehrlich DE, Choi DC, Dabrowska J, Bowers ME, McCullough KM, et al. Thy1-expressing neurons in the basolateral amygdala may mediate fear inhibition. J Neurosci. 2013;33:10396-404.

106. Yoshii T, Hosokawa H, Matsuo N. Pharmacogenetic reactivation of the original engram evokes an extinguished fear memory. Neuropharmacology. 2017;113:1-9.

107. Heldt SA, Mou L, Ressler KJ. In vivo knockdown of GAD67 in the amygdala disrupts fear extinction and the anxiolytic-like effect of diazepam in mice. Transl Psychiatry. 2012;2:e181.

108. Fitzgerald PJ, Pinard CR, Camp MC, Feyder M, Sah A, Bergstrom HC, et al. Durable fear memories require PSD-95. Mol Psychiatry. 2015;20:901-12.

109. Saha R, Knapp S, Chakraborty D, Horovitz O, Albrecht A, Kriebel M, et al. GABAergic synapses at the axon initial segment of basolateral amygdala projection neurons modulate fear extinction. Neuropsychopharmacology. 2017;42:473-84.

110. Raza SA, Albrecht A, Çalışkan G, Müller B, Demiray YE, Ludewig S, et al. HIPP neurons in the dentate gyrus mediate the cholinergic modulation of background context memory salience. Nat Commun. 2017;8:189.

111. Rau V, DeCola JP, Fanselow MS. Stress-induced enhancement of fear learning: an animal model of posttraumatic stress disorder. Neurosci Biobehav Rev. 2005;29:1207-23.

112. Liberzon I, Krstov M, Young EA. Stress-restress: effects on ACTH and fast feedback. Psychoneuroendocrinology. 1997;22:443-53.

113. Armario A, Escorihuela RM, Nadal R. Long-term neuroendocrine and behavioural effects of a single exposure to stress in adult animals. Neurosci Biobehav Rev. 2008;32:1121-35.

114. Richter-Levin G. Acute and long-term behavioral correlates of underwater trauma--potential relevance to stress and post-stress syndromes. Psychiatry Res. 1998;79:73-83.

115. Adamec R, Toth M, Haller J, Halasz J, Blundell J. Activation patterns of cells in selected brain stem nuclei of more and less stress responsive rats in two animal models of PTSD - predator exposure and submersion stress. Neuropharmacology. 2012;62:725-36.

116. Cohen H, Benjamin J, Kaplan Z, Kotler M. Administration of high-dose ketoconazole, an inhibitor of steroid synthesis, prevents posttraumatic anxiety in an animal model. Eur Neuropsychopharmacol. 2000;10:429-35.

117. Zoladz PR, Conrad CD, Fleshner M, Diamond DM. Acute episodes of predator exposure in conjunction with chronic social instability as an animal model of post-traumatic stress disorder. Stress. 2008;11:259-81.

118. Pulliam JV, Dawaghreh AM, Alema-Mensah E, Plotsky PM. Social defeat stress produces prolonged alterations in acoustic startle and body weight gain in male Long Evans rats. J Psychiatr Res. 2010;44:106-11.

119. Koolhaas JM, Bartolomucci A, Buwalda B, de Boer SF, Flügge G, Korte SM, et al. (2011) Stress revisited: a critical evaluation of the stress concept. Neurosci Biobehav Rev. 2011; 35:1291-301.

120. Kessler RC, Berglund P, Demler O, Jin R, Merikangas KR, Walters EE. Lifetime prevalence and age-of-onset distributions of DSM-IV disorders in the National Comorbidity Survey Replication. Arch Gen Psychiatry. 2005;62:593-602.

121. Olaya B, Alonso J, Atwoli L, Kessler RC, Vilagut G, Haro JM. Association between traumatic events and post-traumatic stress disorder: results from the ESEMeD-Spain study. Epidemiol Psychiatr Sci. 2015;24:172-83.

122. Bromet EJ, Atwoli L, Kawakami N, Navarro-Mateu F, Piotrowski P, King AJ. et al. Post-traumatic stress disorder associated with natural and human-made disasters in the World Mental Health Surveys. Psychol Med. 2017;47:227-41.

123. Geerse GJ, van Gurp LC, Wiegant VM, Stam R. Individual reactivity to the open-field predicts the expression of stressinduced behavioural and somatic pain sensitisation. Behav Brain Res. 2006;174:112-8.

124. King JA, Abend S, Edwards E. Genetic predisposition and the development of posttraumatic stress disorder in an animal model. Biol Psychiatry. 2001;50:231-7.

125. Walker SE, Sandi C. Long-term programing of psychopathology-like behaviors in male rats by peripubertal stress depends on individual's glucocorticoid responsiveness to stress. Stress. 2018;7:1-10.

126. Herrero AI, Sandi C, Venero C. Individual differences in anxiety trait are related to spatial learning abilities and hippocampal expression of mineralocorticoid receptors. Neurobiol Learn Mem. 2006;86:150-9.

127. Sandi C, Richter-Levin G. From high anxiety trait to depression: a neurocognitive hypothesis. Trends Neurosci. 2009;32: 312-20.

128. Zovkic IB, Sweatt JD. Epigenetic mechanisms in learned fear: implications for PTSD. Neuropsychopharmacology. 2013;38: 77-93.

129. Reul JM. Making memories of stressful events: a journey along epigenetic, gene transcription, and signaling pathways. Front Psychiatry. 2014;5:5.

130. Zannas AS, Provençal N, Binder EB. Epigenetics of posttraumatic stress disorder: current evidence, challenges, and future directions. Biol Psychiatry. 2015;78:327-35.

131. Bohacek J, Mansuy IM. Molecular insights into transgenerational non-genetic inheritance of acquired behaviours. Nat Rev Genet. 2015;16:641-52.

132. Sheerin CM, Lind MJ, Bountress KE, Nugent NR, Amstadter $\mathrm{AB}$. The genetics and epigenetics of PTSD: overview, recent advances, and future directions. Curr Opin Psychol. 2017; 14:5-11.

133. Hager T, Jansen RF, Pieneman AW, Manivannan SN, Golani I, van der Sluis $\mathrm{S}$, et al. Display of individuality in avoidance behavior and risk assessment of inbred mice. Front Behav Neurosci. 2014;8:314.

134. Heim C, Nemeroff CB. Neurobiology of early life stress: clinical studies. Semin Clin Neuropsychiatry. 2002;7:147-59.

135. Molet J, Maras PM, Avishai-Eliner S, Baram TZ. Naturalistic rodent models of chronic early-life stress. Dev Psychobiol. 2014;56:1675-88.

136. Avital A, Richter-Levin G. Exposure to juvenile stress exacerbates the behavioural consequences of exposure to stress in the adult rat. Int J Neuropsychopharmacol. 2005;8:163-73.

137. Horovitz O, Tsoory MM, Hall J, Jacobson-Pick S, Richter-Levin G. Post-weaning to pre-pubertal ('juvenile') stress: a model of induced predisposition to stress-related disorders. Neuroendocrinology. 2012;95:56-64.

138. Fuentes S, Carrasco J, Armario A, Nadal R. Behavioral and neuroendocrine consequences of juvenile stress combined with 
adult immobilization in male rats. Horm Behav. 2014; $66: 475-86$.

139. Albrecht A, Müller I, Ardi Z, Çalışkan G, Gruber D, Ivens S, et al. Neurobiological consequences of juvenile stress: a GABAergic perspective on risk and resilience. Neurosci Biobehav Rev. 2017;74(Pt A):21-43.

140. Li C, Liu Y, Yin S, Lu C, Liu D, Jiang H, et al. Long-term effects of early adolescent stress: dysregulation of hypothalamicpituitary-adrenal axis and central corticotropin releasing factor receptor 1 expression in adult male rats. Behav Brain Res. 2015;288:39-49.

141. Dirven BCJ, Homberg JR, Kozicz T, Henckens MJAG.. Epigenetic programming of the neuroendocrine stress response by adult life stress. J Mol Endocrinol. 2017;59:R11-R31.

142. Schmidt MV, Abraham WC, Maroun M, Stork O, Richter-Levin G. Stress-induced metaplasticity: from synapses to behavior. Neuroscience. 2013;250:112-20.

143. Hermos JA, Young MM, Lawler EV, Rosenbloom D, Fiore LD. Long-term, high-dose benzodiazepine prescriptions in veteran patients with PTSD: influence of preexisting alcoholism and drug-abuse diagnoses. J Trauma Stress. 2007;20:909-14.

144. Meerlo P, Sgoifo A, Suchecki D. Restricted and disrupted sleep: effects on autonomic function, neuroendocrine stress systems and stress responsivity. Sleep Med Rev. 2008;12:197-210.

145. Horn SR, Charney DS, Feder A. Understanding resilience: new approaches for preventing and treating PTSD. Exp Neurol. 2016;284(Pt B):119-32.

146. Nederhof E, Schmidt MV. Mismatch or cumulative stress: toward an integrated hypothesis of programming effects. Physiol Behav. 2012;106:691-700.

147. Ellis BJ, Del Giudice M. Beyond allostatic load: rethinking the role of stress in regulating human development. Dev Psychopathol. 2014;26:1-20.

148. Shapero BG, Hamilton JL, Stange JP, Liu RT, Abramson LY, Alloy LB. Moderate childhood stress buffers against depressive response to proximal stressors: a multi-wave prospective study of early adolescents. J Abnorm Child Psychol. 2015;43:1403-13.

149. Hsiao YM, Tsai TC, Lin YT, Chen CC, Huang CC, Hsu KS. Early life stress dampens stress responsiveness in adolescence: evaluation of neuroendocrine reactivity and coping behavior. Psychoneuroendocrinology. 2016;67:86-99.

150. Santarelli S, Lesuis SL, Wang XD, Wagner KV, Hartmann J, Labermaier $\mathrm{C}$, et al. Evidence supporting the match/mismatch hypothesis of psychiatric disorders. E Neuropsychopharmacol. 2014;24:907-18.

151. Santarelli S, Zimmermann C, Kalideris G, Lesuis SL, Arloth J, Uribe A, et al. An adverse early life environment can enhance stress resilience in adulthood. Psychoneuroendocrinology. 2017;78:213-21.

152. Cohen H, Zohar J, Matar M. The relevance of differential response to trauma in an animal model of posttraumatic stress disorder. Biol Psychiatry. 2003;53:463-73.

153. Cohen H, Matar MA, Buskila D, Kaplan Z, Zohar J. Early poststressor intervention with high-dose corticosterone attenuates posttraumatic stress response in an animal model of posttraumatic stress disorder. Biol Psychiatry. 2008;64:708-17.

154. Bazak N, Kozlovsky N, Kaplan Z, Matar M, Golan H, Zohar J, et al. Pre-pubertal stress exposure affects adult behavioral response in association with changes in circulating corticosterone and brain-derived neurotrophic factor. Psychoneuroendocrinology. 2009;34:844-58.

155. Cohen H, Liu T, Kozlovsky N, Kaplan Z, Zohar J, Mathé AA. The neuropeptide Y (NPY)-ergic system is associated with behavioral resilience to stress exposure in an animal model of post-traumatic stress disorder. Neuropsychopharmacology. 2012;37:350-63.
156. Horovitz O, Tsoory MM, Yovell Y, Richter-Levin G. A rat model of pre-puberty (juvenile) stress-induced predisposition to stress-related disorders: sex similarities and sex differences in effects and symptoms. World J Biol Psychiatry. 2014;15:36-48.

157. Breslau N, Davis GC, Andreski P, Peterson EL, Schultz LR. Sex differences in posttraumatic stress disorder. Arch Gen Psychiatry. 1997;54:1044-8.

158. Kessler RC, Sonnega A, Bromet E, Hughes M, Nelson CB. Posttraumatic stress disorder in the National Comorbidity Survey. Arch Gen Psychiatry. 1995;52:1048-60.

159. Norris FH, Friedman MJ, Watson PJ, Byrne CM, Diaz E, Kaniasty K. 60,000 disaster victims speak: Part I. An empirical review of the empirical literature, 1981-2001. Psychiatry. 2002;65:207-39.

160. Tolin DF, Foa EB. Sex differences in trauma and posttraumatic stress disorder: a quantitative review of 25 years of research. Psychol Bull. 2006;132:959-92.

161. Stein MB, Walker J, Forde D. (2000). Gender differences in susceptibility to posttraumatic stress disorder. Behav Res Ther. 1995;38:619-28.

162. Hu, J, Feng, B, Zhu, Y, Wang, W, Xie, J, Zheng, X Gender differences in PTSD: susceptibility and resilience. In: Gender differences in different contexts. InTech. (ed.) Aida Alvinius 2142, Rijeka, Croatia 2017.

163. Briscione MA, Michopoulos V, Jovanovic T, Norrholm SD. Neuroendocrine underpinnings of increased risk for posttraumatic stress disorder in women. Vitam Horm. 2017;103: 53-83.

164. Maeng LY, Milad MR. Sex differences in anxiety disorders: interactions between fear, stress, and gonadal hormones. Horm Behav. 2015;76:106-17.

165. Fenchel D, Levkovitz Y, Vainer E, Kaplan Z, Zohar J, Cohen H. Beyond the HPA-axis: the role of the gonadal steroid hormone receptors in modulating stress-related responses in an animal model of PTSD. Eur Neuropsychopharmacol. 2015;25:944-57.

166. Scharfman HE, MacLusky NJ. Differential regulation of BDNF, synaptic plasticity and sprouting in the hippocampal mossy fiber pathway of male and female rats. Neuropharmacology. 2014;76 (Pt C):696-708.

167. Lilly MM, Pole N, Best SR, Metzler T, Marmar CR. Gender and PTSD: what can we learn from female police officers? J Anxiety Disord. 2009;23:767-74.

168. Haskell SG, Gordon KS, Mattocks K, Duggal M, Erdos J, Justice A, et al. Gender differences in rates of depression, PTSD, pain, obesity, and military sexual trauma among Connecticut War Veterans of Iraq and Afghanistan. J Women's Health (Larchmt). 2010;19:267-71.

169. Crum-Cianflone NF, Jacobson I. Gender differences of postdeployment post-traumatic stress disorder among service members and veterans of the Iraq and Afghanistan conflicts. Epidemiol Rev. 2014;36:5-18.

170. Cohen H, Yehuda R. Gender differences in animal models of posttraumatic stress disorder. Dis Markers. 2011;30:141-50.

171. Peters L, Issakidis C, Slade T, Andrews G. Gender differences in the prevalence of DSM-IV and ICD-10 PTSD. Psychol Med. 2006;36:81-9.

172. Hourani L, Williams J, Bray R, Kandel D. Gender differences in the expression of PTSD symptoms among active duty military personnel. J Anxiety Disord. 2015;29:101-8.

173. Pineles SL, Arditte Hall KA, Rasmusson AM. Gender and PTSD: different pathways to a similar phenotype. Curr Opin Psychol. 2017;14:44-48.

174. Gradus JL, Leatherman S, Curreri A, Myers LG, Ferguson R, Miller M. Gender differences in substance abuse, PTSD and intentional self-harm among veterans health administration patients. Drug Alcohol Depend. 2017;171:66-69. 
175. Shors TJ. Opposite effects of stressful experience on memory formation in males versus females. Dialog Clin Neurosci. 2002;4:139-47.

176. Shors TJ, Mathew J, Sisti HM, Edgecomb C, Beckoff S, Dalla C. Neurogenesis and helplessness are mediated by controllability in males but not in females. Biol Psychiatry. 2007;62:487-95.

177. Brydges NM, Wood ER, Holmes MC, Hall J. Prepubertal stress and hippocampal function: sex-specific effects. Hippocampus. 2014;24:684-92.

178. Zitman FM, Richter-Levin G. Age and sex-dependent differences in activity, plasticity and response to stress in the dentate gyrus. Neuroscience. 2013;249:21-30.

179. Jacobson-Pick S, Richter-Levin G. Differential impact of juvenile stress and corticosterone in juvenility and in adulthood, in male and female rats. Behav Brain Res. 2010;214:268-76.

180. Kessler RC, Nelson CB, McGonagle KA, Liu J, Swartz M, Blazer DG. Comorbidity of DSM-III-R major depressive disorder in the general population: results from the U.S. National Comorbidity Survey. Br J Psychiatry. 1996;168:17-30.

181. Kaufman J, Charney D. Comorbidity of mood and anxiety disorders. Depress Anxiety. 2000;12 Suppl:69-76.

182. Alexander JL, Dennerstein L, Kotz K, Richardson G. Women, anxiety and mood: a review of nomenclature, comorbidity and epidemiology. Expert Rev Neurother. 2007;7 11 Suppl:S45-58.

183. Lai HM, Cleary M, Sitharthan T, Hunt GE. Prevalence of comorbid substance use, anxiety and mood disorders in epidemiological surveys, 1990-2014: a systematic review and metaanalysis. Drug Alcohol Depend. 2015;154:1-13.

184. Rytwinski NK, Scur MD, Feeny NC, Youngstrom EA. The cooccurrence of major depressive disorder among individuals with posttraumatic stress disorder: a meta-analysis. J Trauma Stress. 2013;26:299-309.

185. Sher L. New scientific evidence supports the concept of posttraumatic mood disorder and an association of post-traumatic mood disorder with completed suicide. Med Hypotheses. 2010;75:271-2.

186. Auxéméry Y. Clinical forms of post-traumatic depression. Encephale. 2015;41:346-54.

187. Lawrence-Wood E, Van Hooff M, Baur J, McFarlane AC. Reexperiencing phenomena following a disaster: the long-term predictive role of intrusion symptoms in the development of post-trauma depression and anxiety. $\mathrm{J}$ Affect Disord. 2016;190:278-81.

188. American Psychiatric Association. American Psychiatric Association: Diagnostic and Statistical Manual of Mental Disorders: DSM-IV. Washington, DC: American Psichiatric Association; 1994.

189. Tsoory M, Richter-Levin G. Learning under stress in the adult rat is differentially affected by 'juvenile' or 'adolescent' stress. Int J Neuropsychopharmacol. 2006;9:713-28.

190. Tsoory M, Cohen H, Richter-Levin G. Juvenile stress induces a predisposition to either anxiety or depressive-like symptoms following stress in adulthood. Eur Neuropsychopharmacol. 2007; 17:245-56.

191. Patki G, Li L, Allam F, Solanki N, Dao AT, Alkadhi K, et al. Moderate treadmill exercise rescues anxiety and depression-like behavior as well as memory impairment in a rat model of posttraumatic stress disorder. Physiol Behav. 2014;130:47-53.

192. Ji LL, Tong L, Xu BK, Fu CH, Shu W, Peng JB, et al. Intrahippocampal administration of ZIP alleviates depressive and anxiety-like responses in an animal model of posttraumatic stress disorder. Behav Brain Funct. 2014;10:28.

193. Serova LI, Laukova M, Alaluf LG, Pucillo L, Sabban EL. Intranasal neuropeptide $\mathrm{Y}$ reverses anxiety and depressive-like behavior impaired by single prolonged stress PTSD model. Eur Neuropsychopharmacol. 2014;24:142-7.
194. Lin CC, Tung CS, Liu YP. Escitalopram reversed the traumatic stress-induced depressed and anxiety-like symptoms but not the deficits of fear memory. Psychopharmacology (Berlin). 2016;233:1135-46.

195. Cuthbert B, Insel T. The data of diagnosis: new approaches to psychiatric classification. Psychiatry. 2010;73:311-4.

196. Kapur S, Phillips AG, Insel TR. Why has it taken so long for biological psychiatry to develop clinical tests and what to do about it? Mol Psychiatry. 2012;17:1174-9.

197. Macedo T, Wilheim L, Gonçalves R, Coutinho ES, Vilete L, Figueira I, et al. Building resilience for future adversity: a systematic review of interventions in non-clinical samples of adults. BMC Psychiatry. 2014;14:227.

198. Hauger RL, Olivares-Reyes JA, Dautzenberg FM, Lohr JB, Braun S, Oakley RH. Molecular and cell signaling targets for PTSD pathophysiology and pharmacotherapy. Neuropharmacology. 2012;62:705-14.

199. Neylan TC, Schadt EE, Yehuda R. Biomarkers for combatrelated PTSD: focus on molecular networks from highdimensional data. Eur J Psychotraumatol. 2014;5:23938.

200. Muhie S, Gautam A, Meyerhoff J, Chakraborty N, Hammamieh $\mathrm{R}$, Jett $\mathrm{M}$. Brain transcriptome profiles in mouse model simulating features of post-traumatic stress disorder. Mol Brain. 2015;8:14.

201. Logue MW, Smith AK, Baldwin C, Wolf EJ, Guffanti G, Ratanatharathorn A, et al. An analysis of gene expression in PTSD implicates genes involved in the glucocorticoid receptor pathway and neural responses to stress. Psychoneuroendocrinology. 2015;57:1-13.

202. Febbraro F, Svenningsen K, Tran TP, Wiborg O. Neuronal substrates underlying stress resilience and susceptibility in rats. PLoS One. 2017;12:e179434.

203. Southwick SM, Charney DS. The science of resilience: implications for the prevention and treatment of depression. Science. 2012;338:79-82.

204. Wu G, Feder A, Cohen H, Kim JJ, Calderon S, Charney DS. et al. Understanding resilience. Front Behav Neurosci. 2013;7:10

205. Tischer D, Weiner OD. Illuminating cell signalling with optogenetic tools. Nat Rev Mol Cell Biol. 2014;15:551-8.

206. Motta-Mena LB, Reade A, Mallory MJ, Glantz S, Weiner OD, Lynch KW, et al. An optogenetic gene expression system with rapid activation and deactivation kinetics. Nat Chem Biol. 2014;10:196-202.

207. Singh P, Schimenti JC, Bolcun-Filas E. A mouse geneticist's practical guide to CRISPR applications. Genetics. 2015; 199:1-15.

208. Walters BJ, Azam AB, Gillon CJ, Josselyn SA, Zovkic IB. Advanced In vivo use of CRISPR/Cas9 and anti-sense DNA inhibition for gene manipulation in the brain. Front Genet. 2016;6:362

209. Wang P, Zhao D, Lachman HM, Zheng D. Enriched expression of genes associated with autism spectrum disorders in human inhibitory neurons. Transl Psychiatry. 2018;8:13.

210. Reznikov R, Bambico FR, Diwan M, Raymond RJ, Nashed MG, Nobrega JN, et al. Prefrontal cortex deep brain stimulation improves fear and anxiety-like behavior and reduces basolateral amygdala activity in a preclinical model of posttraumatic stress disorder. Neuropsychopharmacology. 2018;43:1099-106.

211. Bachmann AW, Sedgley TL, Jackson RV, Gibson JN, Young RM, Torpy DJ. Glucocorticoid receptor polymorphisms and post-traumatic stress disorder. Psychoneuroendocrinology. 2005;30:297-306.

212. Yehuda R, Pratchett LC, Elmes MW, Lehrner A, Daskalakis NP, Koch E, et al. Glucocorticoid-related predictors and correlates of post-traumatic stress disorder treatment response in combat veterans. Interface Focus. 2014;4:20140048. 
213. Wen L, Han F, Shi Y. Changes in the glucocorticoid receptor and $\mathrm{Ca}^{2+}$ /calreticulin-dependent signalling pathway in the medial prefrontal cortex of rats with post-traumatic stress disorder. J Mol Neurosci. 2015;56:24-34.

214. Kohda K, Harada K, Kato K, Hoshino A, Motohashi J, Yamaji $\mathrm{T}$, et al. Glucocorticoid receptor activation is involved in producing abnormal phenotypes of single-prolonged stress rats: a putative post-traumatic stress disorder model. Neuroscience. 2007;148:22-33.

215. Sarapas C, Cai G, Bierer LM, Golier JA, Galea S, Ising M, et al. Genetic markers for PTSD risk and resilience among survivors of the World Trade Center attacks. Dis Markers. 2011;30:101-10.

216. Mehta D, Gonik M, Klengel T, Rex-Haffner M, Menke A, Rubel $\mathrm{J}$, et al. Using polymorphisms in FKBP5 to define biologically distinct subtypes of posttraumatic stress disorder: evidence from endocrine and gene expression studies. Arch Gen Psychiatry. 2011;68:901-10.

217. Sabbagh JJ, O'Leary JC 3rd, Blair LJ, Klengel T, Nordhues BA, Fontaine SN, et al. Age-associated epigenetic upregulation of the FKBP5 gene selectively impairs stress resiliency. PLoS One. 2014;9:e107241.

218. Criado-Marrero M, Morales Silva RJ, Velazquez B, Hernández A, Colon M, Cruz E, et al. Dynamic expression of FKBP5 in the medial prefrontal cortex regulates resiliency to conditioned fear. Learn Mem. 2017;24:145-52.

219. van der Doelen RH, Calabrese F, Guidotti G, Geenen B, Riva MA, Kozicz T, et al. Early life stress and serotonin transporter gene variation interact to affect the transcription of the glucocorticoid and mineralocorticoid receptors, and the co-chaperone FKBP5, in the adult rat brain. Front Behav Neurosci. $2014 ; 8: 355$.

220. Xu J, Wang R, Liu Y, Liu D, Jiang H, Pan F. FKBP5 and specific microRNAs via glucocorticoid receptor in the basolateral amygdala involved in the susceptibility to depressive disorder in early adolescent stressed rats. J Psychiatr Res. 2017;95:102-13.

221. Amstadter AB, Nugent NR, Yang BZ, Miller A, Siburian R, Moorjani $\mathrm{P}$, et al. Corticotrophin-releasing hormone type 1 receptor gene (CRHR1) variants predict posttraumatic stress disorder onset and course in pediatric injury patients. Dis Markers. 2011;30:89-99.

222. White S, Acierno R, Ruggiero KJ, Koenen KC, Kilpatrick DG, Galea $\mathrm{S}$, et al. Association of CRHR1 variants and posttraumatic stress symptoms in hurricane exposed adults. J Anxiety Disord. 2013;27:678-83.

223. Wolf EJ, Mitchell KS, Logue MW, Baldwin CT, Reardon AF, Humphries DE, et al. Corticotropin releasing hormone receptor 2 (CRHR-2) gene is associated with decreased risk and severity of posttraumatic stress disorder in women. Depress Anxiety. 2013;30:1161-9.

224. Thoeringer CK, Henes K, Eder M, Dahlhoff M, Wurst W, Holsboer F, et al. Consolidation of remote fear memories involves corticotropin-releasing hormone (CRH) receptor type 1mediated enhancement of AMPA receptor GluR1 signaling in the dentate gyrus. Neuropsychopharmacology. 2012;37:787-96.

225. Lebow M, Neufeld-Cohen A, Kuperman Y, Tsoory M, Gil S, Chen A. Susceptibility to PTSD-like behavior is mediated by corticotropin-releasing factor receptor type 2 levels in the bed nucleus of the stria terminalis. J Neurosci. 2012;32:6906-16.

226. Elharrar E, Warhaftig G, Issler O, Sztainberg Y, Dikshtein Y, Zahut R, et al. Overexpression of corticotropin-releasing factor receptor type 2 in the bed nucleus of stria terminalis improves posttraumatic stress disorder-like symptoms in a model of incubation of fear. Biol Psychiatry. 2013;74:827-36.

227. Tyrka AR, Price LH, Gelernter J, Schepker C, Anderson GM, Carpenter LL. Interaction of childhood maltreatment with the corticotropin-releasing hormone receptor gene: effects on hypothalamic-pituitary-adrenal axis reactivity. Biol Psychiatry. 2009;66:681-5.

228. Toth M, Flandreau EI, Deslauriers J, Geyer MA, Mansuy IM, Merlo Pich E, et al. Overexpression of forebrain CRH during early life increases trauma susceptibility in adulthood. Neuropsychopharmacology. 2016;41:1681-90.

229. van der Doelen RH, Arnoldussen IA, Ghareh H, van Och L, Homberg JR, Kozicz T. Early life adversity and serotonin transporter gene variation interact to affect DNA methylation of the corticotropin-releasing factor gene promoter region in the adult rat brain. Dev Psychopathol. 2015;27:123-35.

230. Ressler KJ, Mercer KB, Bradley B, Jovanovic T, Mahan A, Kerley K, et al. Post-traumatic stress disorder is associated with PACAP and the PAC1 receptor. Nature. 2011;470:492-7.

231. Otto C, Martin M, Wolfer DP, Lipp HP, Maldonado R, Schütz G. Altered emotional behavior in PACAP-type-I-receptor-deficient mice. Brain Res Mol Brain Res. 2001;92:78-84.

232. Farkas J, Kovács LÁ, Gáspár L, Nafz A, Gaszner T, Ujvári B, et al. Construct and face validity of a new model for the three-hit theory of depression using PACAP mutant mice on CD1 background. Neuroscience. 2017;354:11-29.

233. Lee HJ, Lee MS, Kang RH, Kim H, Kim SD, Kee BS, et al. Influence of the serotonin transporter promoter gene polymorphism on susceptibility to posttraumatic stress disorder. Depress Anxiety. 2005;21:135-9.

234. Wang Z, Baker DG, Harrer J, Hamner M, Price M, Amstadter A. The relationship between combat-related posttraumatic stress disorder and the 5-HTTLPR/rs25531 polymorphism. Depress Anxiety. 2011;28:1067-73.

235. Xie P, Kranzler HR, Poling J, Stein MB, Anton RF, Brady K, et al. Interactive effect of stressful life events and the serotonin transporter 5-HTTLPR genotype on posttraumatic stress disorder diagnosis in 2 independent populations. Arch Gen Psychiatry. 2009;66:1201-9.

236. Mushtaq D, Ali A, Margoob MA, Murtaza I, Andrade C. Association between serotonin transporter gene promoter-region polymorphism and 4- and 12-week treatment response to sertraline in posttraumatic stress disorder. J Affect Disord. 2012;136:955-62.

237. Wellman CL, Izquierdo A, Garrett JE, Martin KP, Carroll J, Millstein R, et al. Impaired stress-coping and fear extinction and abnormal corticolimbic morphology in serotonin transporter knock-out mice. J Neurosci. 2007;27:684-91.

238. Malikowska N, Fijałkowski Ł, Nowaczyk A, Popik P, Sałat K. Antidepressant-like activity of venlafaxine and clonidine in mice exposed to single prolonged stress - a model of post-traumatic stress disorder. Pharmacodynamic and molecular docking studies. Brain Res. 2017;1673:1-10.

239. Everaerd D, Gerritsen L, Rijpkema M, Frodl T, van Oostrom I, Franke B, et al. Sex modulates the interactive effect of the serotonin transporter gene polymorphism and childhood adversity on hippocampal volume. Neuropsychopharmacology. 2012;37: 1848-55.

240. Belay H, Burton CL, Lovic V, Meaney MJ, Sokolowski M, Fleming AS. Early adversity and serotonin transporter genotype interact with hippocampal glucocorticoid receptor mRNA expression, corticosterone, and behavior in adult male rats. Behav Neurosci. 2011;125:150-60.

241. van der Doelen RH, Deschamps W, D'Annibale C, Peeters D, Wevers RA, Zelena D, et al. Early life adversity and serotonin transporter gene variation interact at the level of the adrenal gland to affect the adult hypothalamo-pituitary-adrenal axis. Transl Psychiatry. 2014;4:e409.

242. Sullivan GM, Ogden RT, Huang YY, Oquendo MA, Mann JJ, Parsey RV. Higher in vivo serotonin-1a binding in posttraumatic 
stress disorder: a PET study with [11C]WAY-100635. Depress Anxiety. 2013;30:197-206.

243. Klemenhagen KC, Gordon JA, David DJ, Hen R, Gross CT. Increased fear response to contextual cues in mice lacking the 5HT1A receptor. Neuropsychopharmacology. 2006;31:101-11.

244. Luo FF, Han F, Shi YX. Changes in 5-HT1A receptor in the dorsal raphe nucleus in a rat model of post-traumatic stress disorder. Mol Med Rep. 2011;4:843-7.

245. Gruber D, Gilling KE, Albrecht A, Bartsch JC, Çalışkan G, Richter-Levin G, et al. 5-HT receptor-mediated modulation of granule cell inhibition after juvenile stress recovers after a second exposure to adult stress. Neuroscience. 2015;293:67-79.

246. Hemmings SM, Martin LI, Klopper M, van der Merwe L, Aitken $\mathrm{L}$, de Wit E, et al. BDNF Val66Met and DRD2 Taq1A polymorphisms interact to influence PTSD symptom severity: a preliminary investigation in a South African population. Prog Neuropsychopharmacol Biol Psychiatry. 2013;40:273-80.

247. Said N, Lakehayli S, El Khachibi M, El Ouahli M, Nadifi S, Hakkou F, et al. Prenatal stress induces vulnerability to nicotine addiction and alters D2 receptors' expression in the nucleus accumbens in adult rats. Neuroscience. 2015;304:279-85.

248. Azzinnari D, Sigrist H, Staehli S, Palme R, Hildebrandt T, Leparc G, et al. Mouse social stress induces increased fear conditioning, helplessness and fatigue to physical challenge together with markers of altered immune and dopamine function. Neuropharmacology. 2014;85:328-41.

249. Hettema JM, Chen X, Sun C, Brown TA. Direct, indirect and pleiotropic effects of candidate genes on internalizing disorder psychopathology. Psychol Med. 2015;45:2227-36.

250. Walder DJ, Trotman HD, Cubells JF, Brasfield J, Tang YL, Walker EF. Catechol-O-methyltransferase modulation of cortisol secretion in psychiatrically at-risk and healthy adolescents. Psychiatr Genet. 2010;20:166-70.

251. O'Tuathaigh CM, Clarke G, Walsh J, Desbonnet L, Petit E, O'Leary C, et al. Genetic vs. pharmacological inactivation of COMT influences cannabinoid-induced expression of schizophrenia-related phenotypes. Int J Neuropsychopharmacol. 2012;15:1331-42.

252. Holmes SE, Girgenti MJ, Davis MT, Pietrzak RH, DellaGioia N, Nabulsi N, et al. Altered metabotropic glutamate receptor 5 markers in PTSD: In vivo and postmortem evidence. Proc Natl Acad Sci USA. 2017;114:8390-5.

253. Bountress K, Sheerin C, Amstadter AB, Mandel H, Voltin J, Wang Z. The relation between GAD1 and PTSD symptoms: shared risk for depressive symptoms. Psychiatry Res. 2017;258:607-8.

254. Bergado-Acosta JR, Sangha S, Narayanan RT, Obata K, Pape $\mathrm{HC}$, Stork O. Critical role of the 65-kDa isoform of glutamic acid decarboxylase in consolidation and generalization of Pavlovian fear memory. Learn Mem. 2008;15:163-71.

255. Sangha S, Narayanan RT, Bergado-Acosta JR, Stork O, Seidenbecher T, Pape HC. Deficiency of the $65 \mathrm{kDa}$ isoform of glutamic acid decarboxylase impairs extinction of cued but not contextual fear memory. J Neurosci. 2009;29:15713-20.

256. Müller I, Obata K, Richter-Levin G, Stork O. GAD65 haplodeficiency conveys resilience in animal models of stress-induced psychopathology. Front Behav Neurosci. 2014;8:265.

257. Miao YL, Guo WZ, Shi WZ, Fang WW, Liu Y, Liu J, et al. Midazolam ameliorates the behavior deficits of a rat posttraumatic stress disorder model through dual $18 \mathrm{kDa}$ translocator protein and central benzodiazepine receptor and neurosteroidogenesis. PLoS One. 2014;9:e101450.

258. Nelson EC, Agrawal A, Pergadia ML, Lynskey MT, Todorov AA, Wang JC, et al. Association of childhood trauma exposure and GABRA2 polymorphisms with risk of posttraumatic stress disorder in adults. Mol Psychiatry. 2009;14:234-5.
259. Jacobson-Pick S, Elkobi A, Vander S, Rosenblum K, RichterLevin G. Juvenile stress-induced alteration of maturation of the GABAA receptor alpha subunit in the rat. Int J Neuropsychopharmacol. 2008;11:891-903.

260. Pibiri F, Nelson M, Guidotti A, Costa E, Pinna G. Decreased corticolimbic allopregnanolone expression during social isolation enhances contextual fear: A model relevant for posttraumatic stress disorder. Proc Natl Acad Sci USA. 2008;105:5567-72.

261. Pinna G, Rasmusson AM. Ganaxolone improves behavioral deficits in a mouse model of post-traumatic stress disorder. Front Cell Neurosci. 2014;8:256.

262. Shaban H, Humeau Y, Herry C, Cassasus G, Shigemoto R, Ciocchi S, et al. Generalization of amygdala LTP and conditioned fear in the absence of presynaptic inhibition. Nat Neurosci. 2006;9:1028-35.

263. Lynch JF, Winiecki P, Gilman TL, Adkins JM, Jasnow AM. Hippocampal GABA(B(1a)) receptors constrain generalized contextual fear. Neuropsychopharmacology. 2017;42:914-24.

264. Heaney CF, Bolton MM, Murtishaw AS, Sabbagh JJ, Magcalas CM, Kinney JW. Baclofen administration alters fear extinction and GABAergic protein levels. Neurobiol Learn Mem. 2012;98:261-71.

265. Fride E, Suris R, Weidenfeld J, Mechoulam R. Differential response to acute and repeated stress in cannabinoid CB1 receptor knockout newborn and adult mice. Behav Pharmacol. 2005;16:431-40.

266. Chhatwal JP, Davis M, Maguschak KA, Ressler KJ. Enhancing cannabinoid neurotransmission augments the extinction of conditioned fear. Neuropsychopharmacology. 2005;30:516-24.

267. Matchynski-Franks JJ, Susick LL, Schneider BL, Perrine SA, Conti AC. Impaired ethanol-induced sensitization and decreased cannabinoid receptor-1 in a model of posttraumatic stress disorder. PLoS One. 2016;11:e0155759.

268. Mota N, Sumner JA, Lowe SR, Neumeister A, Uddin M, Aiello $\mathrm{AE}$, et al. The rs1049353 polymorphism in the CNR1 gene interacts with childhood abuse to predict posttraumatic threat symptoms. J Clin Psychiatry. 2015;76:e1622-3.

269. Lee TT, Hill MN, Hillard CJ, Gorzalka BB. Disruption of periadolescent endocannabinoid signaling modulates adult neuroendocrine and behavioral responses to stress in male rats. Neuropharmacology. 2015;99:89-97.

270. Watkins LE, Han S, Krystal JH, Southwick SM, Gelernter J, Pietrzak RH. Association between functional polymorphism in neuropeptide $\mathrm{Y}$ gene promoter rs 16147 and resilience to traumatic stress in US military veterans. J Clin Psychiatry. 2017;78: e1058-e9.

271. Schmeltzer SN, Vollmer LL, Rush JE, Weinert M, Dolgas CM, Sah R. History of chronic stress modifies acute stress-evoked fear memory and acoustic startle in male rats. Stress. 2015;18:24453.

272. Andero R, Brothers SP, Jovanovic T, Chen YT, Salah-Uddin H, Cameron M, et al. Amygdala-dependent fear is regulated by Oprl1 in mice and humans with PTSD. Sci Transl Med. 2013;5:188ra73.

273. Zhang Y, Simpson-Durand CD, Standifer KM. Nociceptin/ orphanin FQ peptide receptor antagonist JTC-801 reverses pain and anxiety symptoms in a rat model of post-traumatic stress disorder. Br J Pharmacol. 2015;172:571-82.

274. Andero R, Dias BG, Ressler KJ. A role for Tac2, NkB, and Nk3 receptor in normal and dysregulated fear memory consolidation. Neuron. 2014;83:444-54.

275. Pivac N, Kozaric-Kovacic D, Grubisic-Ilic M, Nedic G, Rakos I, Nikolac M, et al. The association between brain-derived neurotrophic factor Val66Met variants and psychotic symptoms in posttraumatic stress disorder. World J Biol Psychiatry. 2012;13:306-11. 
276. Felmingham KL, Dobson-Stone C, Schofield PR, Quirk GJ, Bryant RA. The brain-derived neurotrophic factor Val66Met polymorphism predicts response to exposure therapy in posttraumatic stress disorder. Biol Psychiatry. 2013;73:1059-63.

277. Dai W, Kaminga AC, Wu X, Wen SW, Tan H, Yan J, et al. Brain-derived neurotropic factor Val66Met polymorphism and posttraumatic stress disorder among survivors of the 1998 Dongting Lake Flood in China. Biomed Res Int. 2017;2017:4569698.

278. Felmingham KL, Zuj DV, Hsu KCM, Nicholson E, Palmer MA, Stuart K, et al. The BDNF Val66Met polymorphism moderates the relationship between posttraumatic stress disorder and fear extinction learning. Psychoneuroendocrinology. 2018;91:142-8.

279. Hill JL, Hardy NF, Jimenez DV, Maynard KR, Kardian AS, Pollock CJ, et al. Loss of promoter IV-driven BDNF expression impacts oscillatory activity during sleep, sensory information processing and fear regulation. Transl Psychiatry. 2016;6:e873.

280. Roth TL, Zoladz PR, Sweatt JD, Diamond DM. Epigenetic modification of hippocampal Bdnf DNA in adult rats in an animal model of post-traumatic stress disorder. J Psychiatr Res. 2011;45:919-26.

281. Gorski JA, Balogh SA, Wehner JM, Jones KR. Learning deficits in forebrain-restricted brain-derived neurotrophic factor mutant mice. Neuroscience. 2003;121:341-54.

282. Heldt SA, Stanek L, Chhatwal JP, Ressler KJ. Hippocampusspecific deletion of BDNF in adult mice impairs spatial memory and extinction of aversive memories. Mol Psychiatry. 2007;12:656-70.

283. Soliman F, Glatt CE, Bath KG, Levita L, Jones RM, Pattwell SS, et al. A genetic variant BDNF polymorphism alters extinction learning in both mouse and human. Science. 2010;327:863-6.

284. Young DA, Neylan TC, O'Donovan A, Metzler T, Richards A, Ross JA, et al. The interaction of BDNF Val66Met, PTSD, and child abuse on psychophysiological reactivity and HPA axis function in a sample of Gulf War Veterans. J Affect Disord. 2018;235:52-60.

285. Dincheva I, Pattwell SS, Tessarollo L, Bath KG, Lee FS. BDNF modulates contextual fear learning during adolescence. Dev Neurosci. 2014;36:269-76.

286. Sippel LM, Han S, Watkins LE, Harpaz-Rotem I, Southwick $\mathrm{SM}$, Krystal JH, et al. Oxytocin receptor gene polymorphisms, attachment, and PTSD: results from the National Health and Resilience in Veterans Study. J Psychiatr Res. 2017;94:139-47.

287. Winslow JT, Hearn EF, Ferguson J, Young LJ, Matzuk MM, Insel TR. Infant vocalization, adult aggression, and fear behavior of an oxytocin null mutant mouse. Horm Behav. 2000;37:145-55.

288. Amico JA, Mantella RC, Vollmer RR, Li X. Anxiety and stress responses in female oxytocin deficient mice. J Neuroendocrinol. 2004;16:319-24.
289. Myers AJ, Williams L, Gatt JM, McAuley-Clark EZ, Dobson-Stone C, Schofield PR, et al. Variation in the oxytocin receptor gene is associated with increased risk for anxiety, stress and depression in individuals with a history of exposure to early life stress. J Psychiatr Res. 2014;59:93-100.

290. Kim TY, Chung HG, Shin HS, Kim SJ, Choi JH, Chung MY, et al. Apolipoprotein E gene polymorphism, alcohol use, and their interactions in combat-related posttraumatic stress disorder. Depress Anxiety. 2013;30:1194-201.

291. Johnson LA, Zuloaga DG, Bidiman E, Marzulla T, Weber S, Wahbeh $\mathrm{H}$, et al. ApoE2 exaggerates PTSD-related behavioral, cognitive, and neuroendocrine alterations. Neuropsychopharmacology. 2015;40:2443-53.

292. Olsen RH, Agam M, Davis MJ, Raber J. ApoE isoformdependent deficits in extinction of contextual fear conditioning. Genes Brain Behav. 2012;11:806-12.

293. Krzyzewska IM, Ensink JBM, Nawijn L, Mul AN, Koch SB, Venema A, et al. Genetic variant in CACNA1C is associated with PTSD in traumatized police officers. Eur J Hum Genet. 2018;26:247-57.

294. Bader PL, Faizi M, Kim LH, Owen SF, Tadross MR, Alfa RW, et al. Mouse model of Timothy syndrome recapitulates triad of autistic traits. Proc Natl Acad Sci USA. 2011;108:15432-7.

295. Logue MW, Baldwin C, Guffanti G, Melista E, Wolf EJ, Reardon $\mathrm{AF}$, et al. A genome-wide association study of posttraumatic stress disorder identifies the retinoid-related orphan receptor alpha (RORA) gene as a significant risk locus. Mol Psychiatry. 2013;18:937-42.

296. Frédéric F, Chianale C, Oliver C, Mariani J. Enhanced endocrine response to novel environment stress and lack of corticosterone circadian rhythm in staggerer (Rora $\mathrm{sg} / \mathrm{sg}$ ) mutant mice. J Neurosci Res. 2006;83:1525-32.

297. Lowe SR, Meyers JL, Galea S, Aiello AE, Uddin M, Wildman DE, et al. RORA and posttraumatic stress trajectories: main effects and interactions with childhood physical abuse history. Brain Behav. 2015;5:e00323.

298. Boku S, Toda H, Nakagawa S, Kato A, Inoue T, Koyama T, et al. Neonatal maternal separation alters the capacity of adult neural precursor cells to differentiate into neurons via methylation of retinoic acid receptor gene promoter. Biol Psychiatry. 2015;77:335-44.

299. Van Dijken HH, Van der Heyden JA, Mos J, Tilders FJ. Inescapable footshocks induce progressive and long-lasting behavioural changes in male rats. Physiol Behav. 1992;51: 787-94.

300. McGuire J, Herman JP, Horn PS, Sallee FR, Sah R. Enhanced fear recall and emotional arousal in rats recovering from chronic variable stress. Physiol Behav. 2010;101:474-82. 